\title{
Mangrove vegetation in Amazonia: a review of studies from the coast of Pará and Maranhão States, north Brazil
}

\author{
Moirah Paula Machado de MENEZES ${ }^{*}$, Uta BERGER², Ulf MEHLIG $^{2 *}$ \\ ABSTRACT \\ The present study is a compilation of the literature about vegetation of mangrove forest of the north coast of Brazil. It \\ synthesizes the knowledge about this important ecosystem and lists the currently available literature. The study focuses on \\ the coast of Pará and Maranhão states, which are covered by a continuous belt of mangroves. The mangrove flora comprises \\ six mangrove tree species and several associated species. Mangrove tree height and stem diameter vary as a function of abiotic \\ local stand parameters. Seasonal variation in rainfall and salinity affect the species' phenology and litter fall. Local population \\ use products derived from mangrove plants for different purposes (e.g. fuel; medicinal; rural construction). The increase in \\ the coastal population has given rise to conflicts, which impact on mangrove forest.
}

KEY WORDS: Amazonian mangroves, phenology, litter fall, herbivory, anthropic impacts

\section{Vegetação de manguezais na Amazônia: uma revisão dos estudos da costa dos Estados Pará e Maranhão, norte do Brasil}

\section{RESUMO}

O presente estudo apresenta uma compilação da literatura sobre a vegetação dos manguezais da costa norte do Brasil, apresentando uma síntese do conhecimento e listando a literatura disponível. O estudo se concentra na costa dos estados do Pará e Maranhão que formam um cinturão contínuo de manguezais . Foram contabilizadas seis espécies arbóreas exclusivas de mangue e várias outras associadas. A altura e o diâmetro das árvores de mangue variam em função de parâmetros abióticos locais. As variaçôes sazonais do regime de chuvas e da salinidade afetam a fenologia das espécies e a produção de serapilheira. A população costeira utiliza a flora do manguezal para diferentes fins (ex: combustível, medicinal, construção rural). O aumento da ocupação costeira inicia um processo de impacto para as florestas de mangue e a disponibilidade de seus recursos.

PALAVRAS Chave: Manguezais Amazônicos, fenologia, serapilheira, herbivoria, impacto antrópico

\footnotetext{
1 Instituto de Estudos Costeiros, Universidade Federal do Pará, Campus de Bragança, Brazil.

2 Center for Tropical Marine Ecology, Bremen, Germany.

* Corresponding author: Instituto de Estudos Costeiros, Universidade Federal do Pará, Campus de Bragança. 68600-000. Bragança, Pará, Brazil. e-mail:moirah@ufpa.br

${ }^{*}$ Actual address: Instituto de Estudos Costeiros, Universidade Federal do Pará, Campus de Bragança. 68600-000. Bragança, Pará, Brazil. e-mail: ulf.mehlig@gmx.net
} 


\section{INTRODUCTION}

Mangroves are coastal forests of sheltered tropical and subtropical coastlines. They feature trees with a capacity to survive in a saline or brackish environment under tidal influence (Tomlinson, 1986). Mangroves offer a variety of economically important resources exploited by the coastal human population, and are important as fish nursery (Macnae, 1968; Sasekumar et al., 1992) as well as for coastal protection (Ewel et al., 1998). Their primary production is fundamental for estuarine and coastal food chains (Alongi et al., 1989). Nevertheless, the mangrove ecosystem has been destroyed by construction of shrimp farms, by deforestation, wood cutting, overfishing, pollution and urban development (Spalding et al., 1997). In Brazil, mangroves occur from the Amapá state in the North to Santa Catarina state in the South. The north coast has an area of approximately 8000 $\mathrm{km}^{2}$ of mangroves (Souza-Filho, 2005). Along the coast the states of Pará and Maranhão, mangroves form a continuous belt of about 700000 ha, that is, nearly $85 \%$ of all Brazilian mangroves (Herz, 1991; Lacerda, 1999). In recent years, integrated research into the coastal ecosystems of this area has been initiated (Berger et al., 1999; Prost et al., 2001) and has provided most of the currently available knowledge on mangrove vegetation of the region. However, no summary of this information is available. This review tries to fill this gap by presenting a synthesis of studies on mangrove vegetation of the coasts of Pará and Maranhão states.

\section{DATA COLLECTION}

The literature analysed includes papers published in peer reviewed journals, books, conference proceedings, internal reports of university programs as well as graduate, master and doctorate theses. Examinations of mangrove specimens from the collection of the Herbarium João Murça Pires at the Museu Paraense Emílio Goeldi at Belem (MG) and personal observations complete the information.

\section{STUDY AREA}

We concentrate on the coast of the north-Brazilian states of Pará and Marahão, extending over $650 \mathrm{~km}$ from Marajó Bay (Pará State) to the estuary of river Preguiças (Maranhão State) between $0^{\circ} 13^{\prime} 45^{\prime \prime} S, 48^{\circ} 33^{\prime} 19^{\prime \prime} \mathrm{W}$ and $2^{\circ} 29^{\prime} 32^{\prime \prime} \mathrm{S}$, $43^{\circ} 27^{\prime} 44^{\prime \prime} \mathrm{W}$ (Figure 1). In this region, mangroves can extend more than $40 \mathrm{~km}$ landward following the course of numerous small estuaries and bays (Souza-Filho, 2005). The area is characterised as macrotidal; tidal amplitude varies between $4 \mathrm{~m}$ and $7.5 \mathrm{~m}$ (Souza-Filho, 2005). The tidal regime is semi-diurnal (DHN, 2004). The climate is tropical, warm and humid. The annual mean precipitation is approximately $2300 \mathrm{~mm}$ (Fisch et al., 1998). The mean air temperature is about $26^{\circ} \mathrm{C}$. The region presents a well defined dry season with mean monthly precipitation less than $50 \mathrm{~mm}$, lasting from July to December (Fisch et al., 1998).

\section{TERMINOLOGY}

The present study considers three classes of pore water salinity, according to Santos et al. (1997): brackish, saline and hypersaline, with salinities of $<30 ; 30-60$ and $>60$, respectively.

\section{RESULTS AND DISCUSSION}

\section{FLORISTIC COMPOSITION AND SPECIES DISTRIBUTION}

\section{Major elements of the mangrove forest flora (sensu Tomlinson, 1986)}

Rhizophora mangle L. (Rhizophoraceae) is the most widely distributed mangrove tree species (Prance et al., 1975), and is dominant in estuaries more exposed to the ocean (Almeida, 1996a). A second, less widely distributed Rhizophora species is Rhizophora racemosa G.F.W. Meyer, which occurs in Marajó Bay (Almeida, 1996a). Further south, there is only one other report of $R$. racemosa, from the Preguiças estuary, Maranhão (Santos, 1986). The third species of the genus, Rhizophora harrisonii Leechman, is less frequently reported than the other two species (Figure 2). Only in the Preguiças estuary it is recorded as dominant mangrove tree (Santos, 1986). According to Breteler (1969) and Lima et al. (2005), the salt tolerance of the Rhizophora species increases from less tolerant $R$. racemosa through $R$. harrisonii to $R$. mangle. Low salt tolerance might explain the restriction of $R$. racemosa and $R$. harrisonii to the Marajó bay region (where pore water salinity is about $5-12$, Menezes, unpubl. data; Figure 2) and the Preguiças estuary. However, no detailed investigations have been carried out into the salt tolerance of these species.

Avicennia germinans (L.) L. is the commonest species of the family Avicenniaceae in our area (Figure 3). According to Luz et al. (2000), A. germinans is more frequent in elevated, less inundated areas and under more saline conditions.

Avicennia schaueriana Stapf and Leechman ex Moldenke has been recorded at several locations along the coast (Figure 3), principally near sandy beaches (Amaral et al., 2001; Santos, 2005). This species has nowhere been reported as a major constituent of the mangrove forest in our study area.

Laguncularia racemosa (L.) C.F. Gaertn. (Combretaceae) occurs along the entire coast in saline as well as in brackish water mangroves (Figure 3). This species mostly occupies forest edges, large gaps, riparian sites, and other open areas. There are no records of $L$. racemosa dominated forests. 


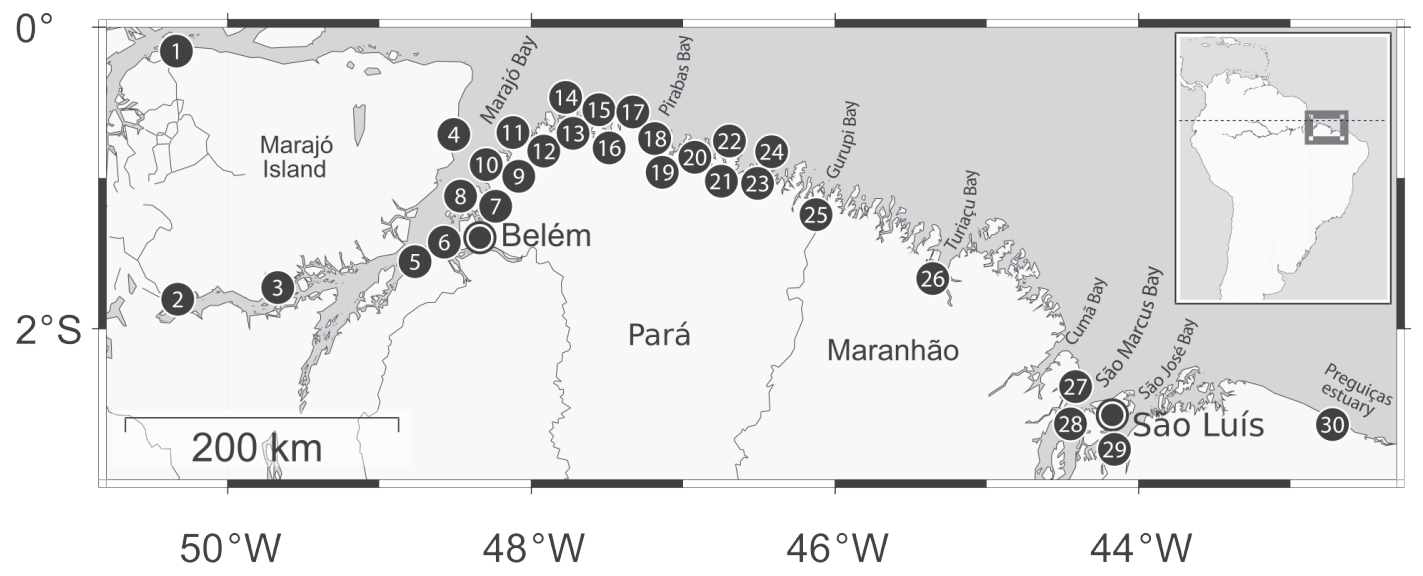

Figure 1 - Study area on the North Coast of Brazil, states of Pará (with the Marajó Island) and Maranhão. Localities with informations about mangrove forests are indicated by numbers (1: Afuá; 2: Breves; 3: São Sebastião da Boa Vista; 4: Soure, Salvaterra; 5: Barcarena; 6: Ilha das Onças; 7: Ananindeua, Marituba and Benevides; 8: Iha do Mosqueiro, Santa Bárbara; 9: Vigia; 10: Colares; 11: São Caetano de Odivelas; 12: Curuçá; 13: Mapanim; 14: Marudá, Praia do Crispim;15: Ilha de Algodoal; 16: Maracanã; 17: Salinas (Salinópolis); 18: São João de Pirabas; 19: Primavera; 20: Quatipuru; 21: Bragança; 22: Ilha de Canelas; 23: Augusto Corrêa; 24: Urumajó; 25: Viseu; 26: Turiaçu; 27: Alcântara; 28: Baía de São José; 29: Baía de São Marcus, Parnauaçu e Rio Mearim 30: Rio Preguiças). For more informations about the geographical position of each site see Annexes.

Table 1 - Minor elements of mangrove forest and species associated to mangrove flora. Bs: brackish mangrove; hs = saline mangrove.

\begin{tabular}{|c|c|c|c|c|}
\hline \multirow{2}{*}{ Family } & \multirow{2}{*}{ Species } & \multicolumn{2}{|c|}{ Sal. } & \multirow{2}{*}{ Reference } \\
\hline & & br & hs & \\
\hline Aizoaceae & Sesuvium portulacastrum & & $\bullet$ & 6; pers. obs. \\
\hline \multirow[t]{2}{*}{ Amaranthaceae } & Alternanthera sp. & $\bullet$ & & 1 \\
\hline & Blutaparon sp. & & $\bullet$ & 6 \\
\hline Amaryllidaceae & Crinum sp. & - & & $10 ; 2 ; 11 ; 20$ \\
\hline Annonaceae & Annona palustris & - & & 15 \\
\hline \multirow[t]{5}{*}{ Apocynaceae } & Mesechites trifidus & - & & 1 \\
\hline & Echites valenzuelanus & - & & 1 \\
\hline & Rhabdadenia biflora & $\bullet$ & - & pers. obs. \\
\hline & Forsteronia sp. & - & & \\
\hline & Mandevilla sp. & - & & $18 ; 19$ \\
\hline Araceae & Montrichardia arborescens & • & & $1 ; 2$ \\
\hline \multirow[t]{3}{*}{ Arecaceae } & Euterpe oleracea & - & & 13 \\
\hline & Mauritia flexuosa & - & & 13 \\
\hline & Astrocaryum vulgare & - & & 18 \\
\hline Bataceae & Batis maritima & & - & 6; pers. obs. \\
\hline \multirow[t]{2}{*}{ Bombacaceae } & Bombax sp. & - & & 12 \\
\hline & $\begin{array}{l}\text { Bombax aquaticum } \\
\text { (=Pachira aquatica) }\end{array}$ & - & & $13 ; 15$ \\
\hline Cecropiaceae & Cecropia sp. & - & & 6 \\
\hline Clusiaceae & Symphonia globulifera & - & & 13 \\
\hline Combretaceae & Conocarpus erectus & & $\bullet$ & $\begin{array}{l}3 ; 4 ; 5 ; 6 ; 7 \\
8 ; 17\end{array}$ \\
\hline Costaceae & Costus arabicus & - & & 1 \\
\hline \multirow[t]{8}{*}{ Cyperaceae } & Cyperus giganteus & - & & 1 \\
\hline & Bulbostylis paraensis & - & & 1 \\
\hline & Cyperus distans & - & & 1 \\
\hline & Cyperus ligularis & - & & 1 \\
\hline & Fimbristylis sp. & & $\bullet$ & 6 \\
\hline & Eleocharis caribaea sp. & & - & 6; pers. obs. \\
\hline & Eleocharis geniculata & & & 19 \\
\hline & Eleocharis intersita & & - & 6 \\
\hline
\end{tabular}

\begin{tabular}{|c|c|c|c|c|}
\hline \multirow{2}{*}{ Family } & \multirow{2}{*}{ Species } & \multicolumn{2}{|c|}{ Sal. } & \multirow{2}{*}{ Reference } \\
\hline & & br & hs & \\
\hline Dennstaedtiaceae & Pteridium aquilinum & $\bullet$ & & 1 \\
\hline Euphorbiaceae & Alchornea brevistyla & $\bullet$ & & 1 \\
\hline \multirow[t]{8}{*}{ Fabacae } & Desmodium canum & $\bullet$ & & 1 \\
\hline & Machaerium lunatum & $\bullet$ & & 9 \\
\hline & Pterocarpus spp. & - & & 12 \\
\hline & Macherium Iunatum & $\bullet$ & & 13 \\
\hline & Pterocarpus rohrii & $\bullet$ & & 15 \\
\hline & Drepanocarpus lunatus & $\bullet$ & & 15 \\
\hline & Inga sp. & $\bullet$ & & 15 \\
\hline & Muellera frutescens & $\bullet$ & & \\
\hline Lythraceae & Crenea maritima & • & & pers. obs. \\
\hline \multirow[t]{3}{*}{ Malvaceae } & Pavonia spicata & $\bullet$ & & \\
\hline & Hibiscus sp. & $\bullet$ & & 6 \\
\hline & Hibiscus tiliaceus & • & & $19 ; 18$ \\
\hline \multirow[t]{2}{*}{ Melastomataceae } & Mouriri angulicosta & $\bullet$ & & 1 \\
\hline & Miconia sp. & $\bullet$ & & 12 \\
\hline \multirow[t]{2}{*}{ Orchidaceae } & Epidendrum ciliare & $\bullet$ & & pers. obs. \\
\hline & Epidendrum sp. & $\bullet$ & & pers. obs. \\
\hline \multirow[t]{5}{*}{ Poaceae } & Sporobulus virginicus & & $\bullet$ & $2 ; 6$ \\
\hline & Spartina alterniflora & $\bullet$ & $\bullet$ & $2 ; 6$ \\
\hline & Spartina brasiliensis & & $\bullet$ & $14 ; 19$ \\
\hline & Cynodon sp. & $\bullet$ & & 1 \\
\hline & Paspalum sp. & & $\bullet$ & 6 \\
\hline Pteridaceae & Acrostichum aureum & $\bullet$ & & $\begin{array}{l}2 ; 6 ; 5 ; 14 \\
16 ; 18 ; 19 \\
18\end{array}$ \\
\hline Rhizophoraceae & Cassipourea guianensis & $\bullet$ & & 15 \\
\hline \multicolumn{5}{|c|}{$\begin{array}{l}\text { References: } 1 \text { Tourinho (1998); } 2 \text { Menezes et al. (2003); } 3 \text { Medina et al. (2001); } 4 \\
\text { Medina et al. (2000); } 5 \text { Lisboa et al. (1993); } 6 \text { Rebelo-Mochel, (1997); } 7 \text { Rebelo- } \\
\text { Mochel et al. (2001); } 8 \text { Carreira et al. (2002); } 9 \text { Adams and Berger (2002); } 10 \text { Berger } \\
\text { et al. (2006); } 11 \text { Matni (2003); } 12 \text { Gama et al. (1996); } 13 \text { Almeida (1996a); } 14 \text { Prost } \\
\text { et al. (2001); } 15 \text { Fereira (1989); } 16 \text { Sales (2000) } 17 \text { Santos et al. (2003); } 18 \text { Almeida } \\
\text { et al. (2002);19 Damasio (1980b);20 Matni et al. (2006) }\end{array}$} \\
\hline
\end{tabular}


Table 2 - Mangrove forest structure. Height: mean height; dbh: mean stem diameter; BA Rhz: Rhizophora Basal Area; BA Av: Avicennia Basal Area; BA Lg: Laguncularia Basal Area; Ag \%: relative density of Avicennia germinans; As \%: relative density of Avicennia schaueriana; Rm \%: relative density of Rhizophora mangle; $\mathrm{Rr} \%$ : relative density of Rhizophora racemosa; $\mathrm{Rh} \%$ : relative density of Rhizophora harrisonii; $\mathrm{Lg} \%$ : relative density of $L$. racemosa; $\mathrm{Rr} \%$ : relative density of Laguncularia racemosa. Locallity: local of each study. For more informations of localities position see Figure 1 and Annexes.

\begin{tabular}{|c|c|c|c|c|c|c|c|c|c|}
\hline \multirow[b]{2}{*}{ Family } & \multirow[b]{2}{*}{ Species } & \multicolumn{2}{|c|}{ Sal. } & \multirow[b]{2}{*}{ Reference } & \multirow[b]{2}{*}{ Family } & \multirow[b]{2}{*}{ Species } & \multicolumn{2}{|c|}{ Sal. } & \multirow[b]{2}{*}{ Reference } \\
\hline & & br & hs & & & & br & hs & \\
\hline Aizoaceae & Sesuvium portulacastrum & & $\bullet$ & 5; pers. obs. & & Eleocharis caribaea* & & $\bullet$ & 5; pers. obs. \\
\hline \multirow[t]{2}{*}{ Amaranthaceae } & Alternanthera sp. & $\bullet$ & & 1 & & Eleocharis geniculata* & & - & 18 \\
\hline & Blutaparon sp. & & $\bullet$ & 5 & & Eleocharis intersita & & $\bullet$ & 5 \\
\hline Amaryllidaceae & Crinum sp. & - & & $9 ; 2 ; 10 ; 19$ & Dennstaedtiaceae & Pteridium aquilinum & - & & 1 \\
\hline Annonaceae & Annona palustris & $\bullet$ & & 14 & Euphorbiaceae & Alchornea brevistyla & $\bullet$ & & 1 \\
\hline \multirow[t]{5}{*}{ Apocynaceae } & Mesechites trifidus & $\bullet$ & & 1 & Fabacae & Desmodium canum & $\bullet$ & & 1 \\
\hline & Echites valenzuelanus & $\bullet$ & & 1 & & Machaerium lunatum & $\bullet$ & & $8 ; 12$ \\
\hline & Rhabdadenia biflora & $\bullet$ & - & pers. obs. & & Pterocarpus spp. & $\bullet$ & & 11 \\
\hline & Forsteronia sp. & $\bullet$ & & & & Pterocarpus rohrii & $\bullet$ & & 14 \\
\hline & Mandevilla sp. & - & & $17 ; 18$ & & Drepanocarpus lunatus & - & & 14 \\
\hline \multirow{2}{*}{ Araceae } & \multirow{2}{*}{$\begin{array}{l}\text { Montrichardia } \\
\text { arborescens }\end{array}$} & \multirow{2}{*}{$\bullet$} & & \multirow{2}{*}{$1 ; 2$} & & Inga sp. & $\bullet$ & & 14 \\
\hline & & & & & & Muellera frutescens & $\bullet$ & & \\
\hline \multirow[t]{3}{*}{ Arecaceae } & Euterpe oleracea & - & & 12 & Lythraceae & Crenea maritima & $\bullet$ & & pers. obs. \\
\hline & Mauritia flexuosa & $\bullet$ & & 12 & Malvaceae & Pavonia spicata & $\bullet$ & & \\
\hline & Astrocaryum vulgare & $\bullet$ & & 17 & & Hibiscus sp. & $\bullet$ & & 5 \\
\hline Bataceae & Batis maritima & & $\bullet$ & 6; pers. obs. & & Hibiscus tiliaceus & $\bullet$ & & $18 ; 17$ \\
\hline \multirow[t]{3}{*}{ Bombacaceae } & Bombax sp. & $\bullet$ & & 11 & Melastomataceae & Mouriri angulicosta & $\bullet$ & & 1 \\
\hline & \multirow{2}{*}{$\begin{array}{l}\text { Bombax aquaticum } \\
\text { (=Pachira aquatica) }\end{array}$} & \multirow{2}{*}{$\bullet$} & & \multirow{2}{*}{$12 ; 14$} & & Miconia sp. & $\bullet$ & & 11 \\
\hline & & & & & Orchidaceae & Epidendrum ciliare & $\bullet$ & & pers. obs. \\
\hline Cecropiaceae & Cecropia sp. & $\bullet$ & & 6 & & Epidendrum sp. & $\bullet$ & & pers. obs. \\
\hline Clusiaceae & Symphonia globulifera & $\bullet$ & & 12 & Poaceae & Sporobulus virginicus & & $\bullet$ & $2 ; 5$ \\
\hline \multirow{2}{*}{ Combretaceae } & \multirow{2}{*}{ Conocarpus erectus } & \multirow{2}{*}{\multicolumn{2}{|c|}{$\bullet$}} & \multirow{2}{*}{$\begin{array}{l}3 ; 4 ; 5 ; 6 ; 7 ; \\
8 ; 16\end{array}$} & & Spartina alterniflora & $\bullet$ & $\bullet$ & $2 ; 5$ \\
\hline & & & & & & Spartina brasiliensis & & $\bullet$ & $13 ; 18$ \\
\hline Costaceae & Costus arabicus & $\bullet$ & & 1 & & Cynodon sp. & $\bullet$ & & 1 \\
\hline \multirow[t]{5}{*}{ Cyperaceae } & Cyperus giganteus & $\bullet$ & & 1 & & Paspalum sp. & & $\bullet$ & 5 \\
\hline & Bulbostylis paraensis & $\bullet$ & & 1 & \multirow{3}{*}{ Pteridaceae } & \multirow{3}{*}{ Acrostichum aureum } & \multirow{3}{*}{$\bullet$} & & \\
\hline & Cyperus distans & $\bullet$ & & 1 & & & & & $15 ; 17 ; 18 ; 17$ \\
\hline & Cyperus ligularis & $\bullet$ & & 1 & & & & & \\
\hline & Fimbristylis sp. & & - & 5 & Rinizopnoraceae & cassipourea gulanensis & - & & 14 \\
\hline
\end{tabular}

References: 1 Tourinho (1998); 2 Menezes et al. (2003); 3 Medina et al. (2001); 4 Lisboa et al. (1993); 5 Rebelo-Mochel, (1997); 6 Rebelo-Mochel et al. (2001); 7 Carreira et al. (2002); 8 Adams and Berger (2002); 9 Berger et al. (2006); 10 Matni (2003); 11 Gama et al. (1996); 12 Almeida (1996a); 13 Prost et al. (2001); 14 Fereira (1989); 15 Sales (2000) 16 Santos et al. (2003); 17 Almeida et al. (2002);18 Damasio (1980b); 19 Matni et al. (2006); * synonymous. 


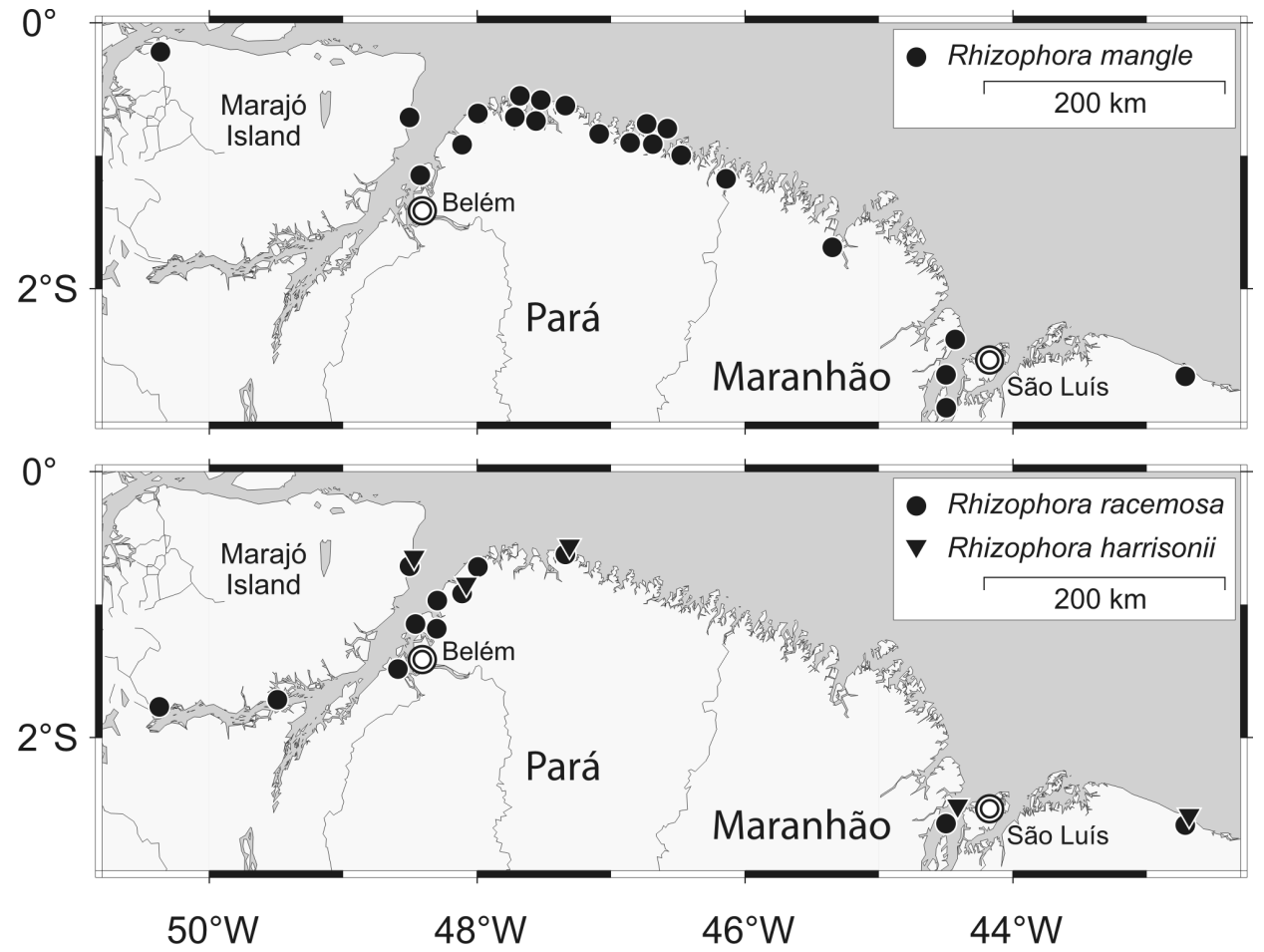

Figure 2 - Distribution of Rhizophora species in the study area. For details about the localities name and position, see Annex 1.

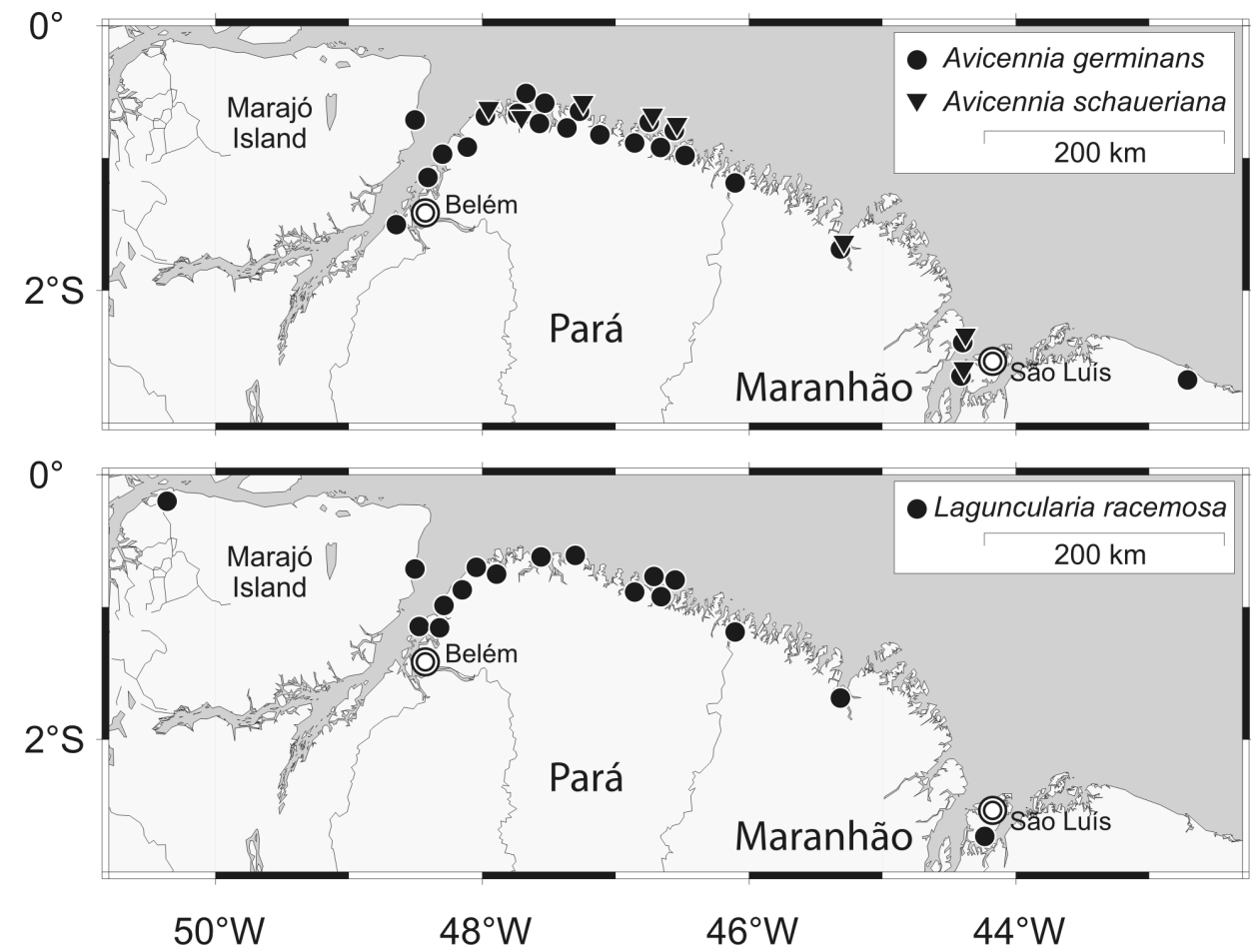

Figure 3 - Distribution of Avicennia species (above) and L. racemosa (below) on the study area. For details about the localities name and position, see Annex 2 and 3. 


\section{Minor elements of mangrove forest and associated species (sensu Tomlinson, 1986)}

Among the species cited as mangrove associates (Table 1 ), only a few occur under high salinity conditions (salinity >30). Most of these are halophytic herbs more frequently found at channel borders or in other open areas; a few are salt marsh species (Carlton, 1975). The only woody high salinity mangrove associate is Conocarpus erectus L. (Combretaceae), which mainly colonises ecotones of mangroves and salt marshes where the soil is sandier and less frequently inundated. A few shrubs and vines (Muellera-Fabaceae-Faboideae, Rhabdadenia - Apocynaceae) have been observed by the authors in saline environments (salinity $>30$ ) on Ajuruteua Peninsula, Bragança. However, most of the woody mangrove associates, as well as herbs like Crinum sp. (Amaryllidaceae) and the mangrove fern Acrostichum (Pteridaceae), seem to be unable to thrive without significant freshwater influence. A number of species cited in the literature might in fact be of terrestrial origin (e.g., Astrocaryum, Cassipourea) and thus belong to adjacent ecosystems like restinga (dune vegetation). Other species may be occasional invaders from temporary flooded upstream fresh water habitats (Várzea).

\section{FOREST STRUCTURE}

Schaeffer-Novelli et al. (1990) divide the Brazilian coast into 7 segments. The mangroves of our study area ("segment III") are classified as Rhizophora-dominated "fringe forests", reaching $20 \mathrm{~m}$ in height. Nevertheless, our review reveals considerable heterogeneity in species composition and forest structure and indicates that this classification is too coarse. Unfortunately, the majority of studies is merely descriptive and does not provide quantitative data based on an adequate sampling area. Furthermore, the methods used to describe forest structure include a variety of plot-based methods and distance-based methods (point-centred quarter method), as well as "rapid assessment" estimation techniques. This means that comparisons of the results of the studies (summarised in Table 2) should be viewed with caution. A maximum average canopy height of approximately $25 \mathrm{~m}$ was observed by Ferreira (1989) in a mature mangrove forest in Vigia, Pará (location 9 in Figure 1). Average trunk diameter at breast height (dbh) can reach $42 \mathrm{~cm}$ in Curuçá, location 12 in Figure 1 (Menezes, 1994). Individual A. germinans trees occasionally attain 100 $\mathrm{cm} \mathrm{dbh}$ in Salvaterra, location 4 in Figure 1 (Lisboa et al., 1993); even larger trees with heights over $30 \mathrm{~m}$ and diameters greater than $1.5 \mathrm{~m}$ were observed by Thüllen (1997) at Furo do Meio, on Ajuruteua Peninsula (location 21 in Figure 1).

In hypersaline and rarely inundated areas, $A$. germinans forms monospecific dwarf forests (Santos et al., 1997; Reise, 2003) with tree heights of less than $2.5 \mathrm{~m}$ (Table 2). Lara and Cohen (2006) observed an inverse relationship between salinity and tree height. Studies of leaf gas exchange (Brabo, 2004) and chlorophyll fluorescence (Hu, 2004) of A. germinans, A. schaueriana and $L$. racemosa trees indicate that salt stress reaches critical levels under conditions found in a rarely inundated, hypersaline (salinity -90$)$ dwarf tree stand on Ajuruteua Peninsula. However, no comparable stress response was detected at a moderately saline, wellinundated site (Brabo, 2004; Hu, 2004). Likewise, results of dendrochronological analyses undertaken by Menezes et al. (2003a) in the same area show similar stem growth rates of $R$. mangle trees from brackish and from saline, well inundated mangrove stands. However, additional research is required to improve our understanding of the influence of environmental factors on the growth of Amazonian mangrove trees and, consequently, on the structure of the mangrove forests in the region. The scope of current research should be broadened to include other tree species and cover additional study sites besides Ajuruteua Peninsula.

Satellite image analyses carried out for the Ajuruteua Peninsula reveal geobotanical units (Souza-Filho and Paradella, 2002; Cohen et al., 2004) which can be mapped to the forest types identified by terrestrial forest structure analysis (Thüllen, 1997, Reise, 1999; 2003; Mehlig, 2001; Menezes et al., 2003a). By matching the results obtained by both the remote sensing and the ground-based approach (and from analyses of flooding regimes and salinity conditions undertaken by Cohen et al., 2004), the following mangrove forest types can be distinguished on Ajuruteua Peninsula:

1) Avicennia germinans dwarf forest (mean tree height $<2.5 \mathrm{~m}$; Reise, 1999; 2003) at highest elevations (above mean spring tide level, inundation frequency $<28 \mathrm{~d} \cdot \mathrm{y}^{-1}$ ); pore water salinity $90-100$.

2) Low $A$.germinans forest (mean tree height $6 \mathrm{~m}$, mean dbh $5 \mathrm{~cm}$; Reise, 1999) in areas inundated only during normal spring tides $\left(28-78 \mathrm{~d} \cdot \mathrm{y}^{-1}\right)$; pore water salinity $90-50$.

3) A. germinans-dominated, tall mixed forests (mean height $11.8 \mathrm{~m}$, mean dbh $19.2 \mathrm{~cm}$; Menezes et al., 2003a); inundated for about $175 \mathrm{~d} \cdot \mathrm{y}^{-1}$; pore water salinity $23-58$.

4) Tall, mixed $R$. mangle/A. germinans forests (mean height $12 \mathrm{~m}$, mean dbh $31 \mathrm{~cm}$; Menezes et al., 2003a), composed of $R$. mangle, A. germinans and Laguncularia racemosa, but dominated by $R$. mangle; at mid-tide level, normally well inundated (up to $233 \mathrm{~d} \cdot \mathrm{y}^{-1}$ ); pore water salinity $20-60$.

4a) A variety of the forest type Tall, mixed R. mangle/A. germinans forests (type 4) occurs under brackish conditions; it has similar structural properties, but features a greater number of associated understorey species (Menezes et al., 2003a; Berger et al., 2006). The pore water salinity ranges from 10 to 17 and inundation frequency is about 140 
Table 3- Phenology of Amazonian mangrove species. $\bullet=$ new leaves/flowers/ fruits observed; $\mathbf{a}=$ peak period.

\begin{tabular}{|c|c|c|c|c|c|c|c|c|c|c|c|c|}
\hline Species & $\mathbf{J}$ & $\mathbf{F}$ & M & A & M & $J$ & $J$ & A & $S$ & 0 & N & D \\
\hline \multicolumn{13}{|l|}{ A. germinans $s^{1,2,5}$} \\
\hline leaves & $\bullet$ & $\bullet$ & $\bullet$ & $\bullet$ & $\bullet$ & $\bullet$ & $\bullet$ & $\bullet$ & - & - & 口 & $\bullet$ \\
\hline flowers & $\bullet$ & & & & & & & $\bullet$ & d & $\bullet$ & $\bullet$ & $\bullet$ \\
\hline fruits & $\bullet$ & $\bullet$ & - & D & & & & & & & & $\bullet$ \\
\hline \multicolumn{13}{|l|}{ A. schaueriana ${ }^{3,5}$} \\
\hline bud & & & & & & $\bullet$ & $\bullet$ & $\bullet$ & & & & \\
\hline flowers & & & & $\bullet$ & $\bullet$ & - & - & $\bullet$ & $\bullet$ & $\bullet$ & & \\
\hline fruits & $\bullet$ & d & - & $\bullet$ & & $\bullet$ & $\bullet$ & & $\bullet$ & & & $\bullet$ \\
\hline R. mangle $1,2,4,7$ & & & & & & & & & $\bullet$ & & & \\
\hline leaves & - & d & D & - & d & - & $\bullet$ & $\bullet$ & $\bullet$ & $\bullet$ & $\bullet$ & $\bullet$ \\
\hline flowers & $\bullet$ & $\bullet$ & $\bullet$ & $\bullet$ & व & - & - & - & $\bullet$ & $\bullet$ & $\bullet$ & $\bullet$ \\
\hline fruits & $\bullet$ & $\bullet$ & $\bullet$ & $\bullet$ & $\bullet$ & $\bullet$ & & & - & - & - & $\bullet$ \\
\hline propagules & - & - & - & $\bullet$ & & & & & & & & \\
\hline \multicolumn{13}{|l|}{ R. racemosa ${ }^{3}$} \\
\hline buds & & $\bullet$ & $\bullet$ & & $\bullet$ & $\bullet$ & & & $\bullet$ & $\bullet$ & & $\bullet$ \\
\hline flowers & $?$ & & & & & & & & & & & \\
\hline fruits & $\bullet$ & $\bullet$ & $\bullet$ & $\bullet$ & $\bullet$ & $\bullet$ & $\bullet$ & $\bullet$ & $\bullet$ & $\bullet$ & $\bullet$ & $\bullet$ \\
\hline propagules & & & $\bullet$ & $\bullet$ & & & & & $\bullet$ & $\bullet$ & & $\bullet$ \\
\hline \multicolumn{13}{|l|}{ L. racemosa $a^{1,6}$} \\
\hline leaves & $\bullet$ & d & $\bullet$ & $\bullet$ & $\bullet$ & - & $\bullet$ & $\bullet$ & $\bullet$ & $\bullet$ & $\bullet$ & \\
\hline flowers & $\bullet$ & $\bullet$ & $\bullet$ & $\bullet$ & $\bullet$ & & & & & & & $\bullet$ \\
\hline fruits & - & - & - & d & $\bullet$ & & & & & & & \\
\hline
\end{tabular}

References: 'Mehlig (2001); ${ }^{2}$ Carvalho (2002); ${ }^{3}$ MPEG Herbarium (MG); ${ }^{4}$ Menezes (1997); ${ }^{5}$ Santos (2005); ${ }^{6}$ Silva (2005); 'Mehlig (2006)

$d \cdot y^{-1}$. These forests occupy inner parts of the estuary with pronounced influence of fresh water runoff.

In addition to the forest types described so far, other forest types can be identified as: 1) regenerating forests consisting of seedlings and/or young trees of L. racemosa and A. germinans; 2) degraded areas with totally or partially dead vegetation (due to damage caused by human activities or changes in local conditions).
All types of forests occur side by side on the peninsula as can be seen clearly in aerial photographs (Reise, 2003) and satellite images (Souza-Filho and Paradella, 2002; Cohen $e t$ al., 2003). The forest types so far described indicate that in spite of the low species richness there is a great deal of variation in mangrove forest structure, corresponding to topographical and hydrological conditions. Since the geomorphological settings and hydrographic conditions in other regions of the Brazilian north coast are comparable to those on Ajuruteua Peninsula (Souza-Filho and Paradella, 2002), vegetation patterns observed here are expected to be typical of the region as whole. Investigations on forest structure of other areas should confirm this conclusion

\section{PHENOLOGY OF MANGROVE TREES}

Information on mangrove phenology is derived from studies of litter fall (Mehlig, 2001; Reise, 2003; Mehlig, 2006; all from Bragança - locality 21 in Figure1), direct observation of phenophases of whole trees (Carvalho, 2002 in Bragança - locality 21 in Figure1), and periodic monitoring of individually marked shoots (Menezes, 1997 at Curuçá, locality 12 in Figure 1; Silva, 2005; Santos, 2005; Mehlig, 2006 - all at Bragança - locality 21 in Figure1). Information on the phenology of $R$. racemosa is based on an analysis of specimens from the João Murça Pires Herbarium at the Paraense Emílio Goeldi Museum fo Pará (MG) in Belém. There are no data on phenology of $R$. harrisonii.

A. germinans leaf fall is seasonal and preceeds flowering (Mehlig, 2001; Carvalho, 2002). New leaves appear mainly during the transition from rainy to dry season when the salt stress is lower (Mehlig, 2001; Santos, 2005). Median leaf life time is 275 days (Santos, 2005). Flowering is restricted to the dry season (Mehlig, 2001; Carvalho, 2002; Santos, 2005). Ripe fruits are released in the rainy season (Table 3; Carvalho, 2002). The time span between peak of flowering and fruit fall is 4-5 months (Mehlig, 2001).

Information on the phenology of $A$. schaueriana is based on observations by Santos (2005). Leaves are produced throughout the year but higher production rates were observed during the rainy season. No clear pattern in leaf

Table 4 - Annual litter fall rates $\left(\mathrm{Mg}^{-1} \cdot \mathrm{ha}^{-1} \cdot \mathrm{y}\right)$ from different locations on Ajuruteua Peninsula, Bragança, Pará state.

\begin{tabular}{|c|c|c|c|}
\hline Site & Position & $\begin{array}{l}\text { Litter dry matter } \\
\left(\mathrm{Mg}^{-1} \cdot \mathrm{ha}^{-1} . \mathrm{y}\right)\end{array}$ & Reference \\
\hline Furo do Meio & $0^{\circ} 52^{\prime} 17^{\prime \prime} \mathrm{S} ; 46^{\circ} 39^{\prime} 00^{\prime \prime} \mathrm{W}$ & 12.8 & Mehlig (2001) \\
\hline Acarajó & $1^{\circ} 00^{\prime} 44^{\prime \prime} \mathrm{S} ; 46^{\circ} 45^{\prime} 44^{\prime \prime} \mathrm{W}$ & 13.1 & Mehlig (2001) \\
\hline Furo Grande I & 0०50'19"'S;46³8'15”'W & 7.9 & Carvalho (2002) \\
\hline Furo Grande II & 050'47'”; $46^{\circ} 38^{\prime} 51^{\prime \prime} \mathrm{W}$ & 15.4 & Reise (2003) \\
\hline Dwarf Forest & $0^{\circ} 53^{\prime} 98^{\prime \prime} \mathrm{S} ; 46^{\circ} 40^{\prime} 32^{\prime \prime} \mathrm{W}$ & 4.1 & Reise (2003) \\
\hline Furo Grande III & $0^{\circ} 50^{\prime} 25^{\prime \prime} \mathrm{S} ; 46^{\circ} 38^{\prime} 20^{\prime \prime} \mathrm{W}$ & 16.3 & Nordhaus (2004) \\
\hline Central peninsula & $0^{\circ} 55^{\prime} 40^{\prime \prime} \mathrm{S} ; 46^{\circ} 40^{\prime} 20^{\prime \prime} \mathrm{W}$ & 11.8 & Nascimento et al. (2006) \\
\hline Bosque de Avicennia & 055'65"S;4640'09'”W & 9.5 & Batista (2003) \\
\hline
\end{tabular}


fall is discerned. The median life span of leaves is 115 days. Flowering takes place from April to October; ripe fruits are observed during the rainy season (Table 3 ).

L. racemosa sheds leaves throughout the year (Mehlig, 2001). New leaves are produced throughout the year at wellinundated sites but production rates are higher during the rainy season. Median leaf life time is 100 days (Silva, 2005). L. racemosa starts flowering mostly at the beginning of the rainy season (Table 3). Fruits develop quickly and are shed in the rainy season (Mehlig, 2001; Silva, 2005).

$R$. mangle sheds leaves throughout the year and new leaves are also produced continuously. Leaf production is higher in the rainy season (Table 3), when soil salinity is lower. Leaf age is variable but rarely exceeds one year (Mehlig, 2006). $R$. mangle also produces flowers throughout the year, but flowering peaks at the end of the rainy season (Menezes, 1997; Mehlig, 2001; Carvalho, 2002; Mehlig, 2006). Propagule release is mostly restricted to the rainy season (Menezes, 1997; Mehlig, 2006; Carvalho, 2002). The time span between pollination and maturation of propagules is about 8 months (Menezes, 1997; Mehlig, 2006). According to Mehlig (2001), the comparison of propagule production between brackish and saline mangroves suggests that differences in salinity regime might play a role in premature abscission of flowers and fruits.

Buds and immature propagules are present in almost all examined herbarium specimens of $R$. racemosa. It is thus probable that flowering and propagule development in $R$. racemosa take place throughout the year (Table 3).

Generalisations based on the currently available phenological data should be avoided due to the small geographic range covered so far. However, differences in patterns of rainfall (for example in the duration of rainy and dry seasons) probably influence the extension and intensity of the phenophases.

\section{LITTER FALL}

Information about mangrove litter fall is available from Ajuruteua Peninsula (Schories and Reise, 2000; Mehlig, 2001; Carvalho, 2002; Reise, 2003; Nordhaus, 2004; Table 4). In all studies, leaves are the most abundant component of the litter (about $70 \%$ of total litter). Litter fall rates range between $4.1 \mathrm{Mg}^{-1} \cdot \mathrm{ha} \cdot \mathrm{y}^{-1}$ in A. germinans dwarf forest (Schories and Reise, 2000) and $16.3 \mathrm{Mg}^{-1} \cdot h a \cdot y^{-1}$ in tall, mixed R. mangle/A. germinans forest (Nordhaus, 2004; Nordhaus et al., 2006). Comparing mangroves with similar structural characteristics on Ajuruteua Peninsula, Schories and Reise (2000) identify salinity as the principal factor affecting the total litter production; the most productive forests are frequently inundated and are characterised by lower salinity. Schories et al. (2003) estimate that less than $31 \%$ of the litter production of a mangrove stand at Furo do Meio on Ajuruteua Peninsula is exported to the estuary by tidal flushing.

\section{LEAF DECOMPOSITION}

Leaf decomposition was analysed through mesh bag exposure experiments by Sales (2000), at São Caetano de Odivelas east of the Marajó Bay ( $\left.0^{\circ} 44^{\prime} 50^{\prime \prime} S, 48^{\circ} 01^{\prime} 16^{\prime \prime} \mathrm{W}\right)$, and Schories et al. (2003) at Furo do Meio on Ajuruteua Peninsula. In both studies, $A$. germinans leaves decomposed faster than those of R. mangle and L. racemosa. Decomposition of $50 \%$ of the exposed material lasted 34 and 90 days for A. germinans and $R$. mangle, respectively (Sales, 2000). Schories et al. (2003) found slightly faster decomposition rates at frequently inundated than at rarely inundated sites (23-34 vs. 29-41 days, respectively). Sales (2000) unfortunately does not specify the inundation regime at his experimental site.

\section{HERBIVORY}

A. germinans is described as the tree species most affected by herbivores, while $R$. mangle is considered the least affected species (Pontes and Mochel, 2000; Rebelo-Mochel, 1997; Ohana et al., 1996; Praxedes and Mello, 1998; Praxedes et al., 1998). The most common predators of mangrove vegetation are Hymenoptera (Praxedes and Mello, 1998; Pontes and Mochel, 2000), crustaceans, Isoptera, Hemiptera (Pontes and Mochel, 2000) and Lepidoptera (Pontes and Mochel, 2000; Menezes and Mehlig, 2005). According to Pontes and Mochel (2000), L. racemosa is severely affected by herbivores in areas polluted by waste-water discharges. Pontes and Mochel (2000) attribute herbivore activity on L. racemosa trees to increased nitrogen concentration in the leaves caused by sewage. A massive infestation of $A$. germinans by caterpillars of the moth Hyblaea puera (Hyblaeidae) was documented on Ajuruteua Peninsula in 1998 (Mehlig and Menezes, 2005), leading to complete defoliation of $A$. germinans-dominated stands. This phenomenon contributed to a decrease in litter fall (Mehlig, 2001). Similar observations were made in the same area in 2000 (Reise, 2003) and in São Caetano de Odivelas (Sousa, 2001; Prost et al., 2001).

\section{ANTHROPIC USES OF MANGROVE FLORA}

Mangrove wood is utilized as fuel and as material for rural construction; poles are extracted for the construction of fish traps (Bastos, 1995; Almeida, 1996b; Rebelo-Mochel, 1997; Glaser and Grasso, 1998; Santana, 2001; Senna et al., 2002; Glaser et al., 2003). Rhizophora bark is used for tannin extraction. Glaser et al. (2003) identify two types of timber extraction: "basic needs" extraction and extraction for commercial purposes. "Basic needs" extractors utilize mangrove products for subsistence (domestic fuel, fish traps). Commercial extraction of wood and bark is an activity not talked about openly because it is illegal under Brazilian law. 
However, the commercial use of the mangrove trees contributes to the income of a considerable number of households (Glaser et al., 2003). R. mangle is the most exploited species. Almeida (1996b) explains the apparent preference for $R$. mangle wood over that of the Avicennia species as reflecting the greater abundance of the former species, but considers wood of Avicennia as equally suitable or even better for construction. Large Rhizophora trees can be felled quite easily by cutting their stilt roots. Large $A$. germinans trees are often hollow and thus not suitable for certain uses. However, large trees of either species are rarely extracted because the transport of logs through the mangrove swamp is usually not viable (they do not float) and stems cannot always be sawn into transportable pieces in situ (pers. obs.).

Bark, leaves and young roots from $R$. mangle, Conocarpus erectus and the grass Spartina alterniflora are used in traditional popular medicine (Bastos, 1995; Almeida, 1996b). During its flowering period, A. germinans attracts honeybees kept by locals. "Mangrove honey" is an appreciated product in the region, but its commercial potential has not been assessed so far. To collect the honey of feral honey bees, locals occasionally cut down trees (Rebelo-Mochel, 1997).

\section{IMPACTS OF HUMAN ACTIVITIES AND PERSPECTIVES OF MANGROVE RECOVERY}

The coastal zone is subjected to diverse anthropogenic pressures due to exploitation and human occupation (Szlafsztein, 2003). Mangrove areas are impacted by clay extraction, aquaculture, agriculture, salt extraction and industrial activities (Senna et al., 2002), and may also be affected by recreational activities (Szlafsztein, 2003). Near urban centers, pollution can affect the ecosystem; RebeloMochel et al. (2001) describe oil spillages and waste dumping as responsible for mangrove destruction around the city of São Luis. On the other hand, mangroves are important for subsistence of the coastal population. For example, in coastal villages of Bragança district, $80 \%$ of the population depend on mangrove products for a variety of subsistence uses (Glaser, 2003). Tourinho (1998) reports the establishment and subsequent abandonment of rice paddy fields in freshwater-influenced mangroves near Acarajó in the Caeté estuary. Rice cultivation failed because farmers were unable to control invasive weeds. Secondary succession of abandoned areas started with colonisation by salt marsh and swamp vegetation, then by $L$. racemosa and finally by $A$. germinans. However, regenerating areas are still distinctly different from the original $R$. mangle dominated forest, which is preserved in the surrounding areas. This case study shows that, even under benign environmental conditions, the recovery of deforested or degraded areas to the original ecosystem state is not straightforward (Berger et al. 2006).
Changes of the hydrographic regime caused by construction of a causeway through mangrove forests on Ajuruteua Peninsula have led to die-back of more than $2 \mathrm{~km}^{2}$ of mangrove forest along a $25 \mathrm{~km}$ section of the PA 458 highway. The new road blocked several tidal channels, reducing the inundation frequency in some areas and leading to prolonged or permanent inundation in others (Souza-Filho, 2001; Carvalho, 2000; Krause et al. 2001). A natural resilience is observed in parts of the area, where L. racemosa trees are successfully colonising the bare mudflat. According to Cohen and Lara (2003), the degraded area decreased by $6.6 \%$ per year during 1986-1988 and 0.04\% in 1991-1997.

Loss and gain of mangrove vegetation along the coast line of Pará has been monitored by means of satellite images (Souza-Filho, 2001; Souza-Filho and Paradella, 2002; Cohen and Lara, 2003). In 1972 the same study area had a mangrove coverage of about $592 \mathrm{~km}^{2}$, which declined to 585,583 and 573 in 1986, 1991 and 1997, respectively. The overall net loss of mangrove vegetation coverage in the 1972-1997 period was $19 \mathrm{~km}^{2}$, a total net loss of $3.2 \%$, which is approximately $0.76 \mathrm{~km}^{2} \cdot \mathrm{yr}^{-1}$ (Cohen and Lara, 2003). Mangrove losses are associated with erosion or are the result of sand deposits asphyxiating mangrove roots (Souza-Filho, 2001; Souza-Filho and Paradella, 2002; Cohen and Lara, 2003). New mangroves can develop following the colonisation of emerging mud banks by Spartina grass or Laguncularia racemosa (Prost et al., 2001; Menezes et al., 2003b).

Analyses of Landsat images and pollen profiles from soil cores by Behling et al. (2002) document a long-term expansion of mangroves on Ajuruteua Peninsula towards higher elevation salt flats with herbaceous vegetation. This expansion may be due to rising sea levels (Lara and Cohen, 2002).

\section{CONCLUSION AND OUTLOOK}

This review demonstrates that the knowledge about mangrove vegetation in Amazonia is still somewhat scarce. The majority of studies is based on rapid assessment making a more detailed analysis difficult. A notable exception are the studies on Ajuruteua Peninsula, Bragança, Pará. However, it seems necessary to replicate the research effort made at this particular point in a number of other places along the Brazilian north coast before being able to describe the mangroves of Amazonia more conclusively. Further, the almost complete lack of long-time monitoring studies e. g. of litter fall or of forest development makes it difficult to elaborate management decisions regarding mangrove vegetation. The recent creation of Marine Extractivist Reserves (reservas extrativistas marinhas, RESEXM) by the Brazilian Institute for Environment and Renewable Natural Resources (Instituto Brasileiro do Meio Ambiente e Recursos Naturais Renováveis, IBAMA) along the coast of Pará state documents that decision 
makers have recognized the need to protect the important resources provided by mangrove vegetation. However, without supplementing the current knowledge through continuation and intensification of mangrove research, the success of mangrove management is at stake.

Nevertheless, the information available so far already allows to characterise the north Brazilian mangroves with more detail than has been done so far, and permits to formulate more specific future research goals. Previous works have underlined chiefly the supposed climatic optimum for mangrove growth near the equator, leading to "better developed" mangrove forests in Amazonia than in the Brazilian Northeast and South (Schaeffer-Novelli et al., 1990; Kjerve and Lacerda, 1992; Lacerda, 1999). Saenger and Snedaker (1993) expect that structural complexity of mangroves is increasing towards the northern and southern geographical limits of mangrove vegetation. While indeed mangrove forests under moderate salinities and high inundation frequencies reach greater tree heights and stem diameters along the north coast than further south, a closer look reveals that climatically benign conditions cannot compensate for growth limitations imposed by other factors, in particular low inundation frequency and the concomitant increase in soil pore water salinity. Consequently, structural variability and floristic differences within mangroves of the Brazilian north coast are greater than reported in the past. Likewise, litter fall rates are not homogeneously high but vary between $<4$ and $>16 \mathrm{Mg} \cdot \mathrm{ha}^{-1} \mathrm{y}^{-1}$, corresponding closely to structural development of the forest stand in question. While maximum litter fall rates are world-wide among the highest reported so far as predicted by Saenger and Snedaker (1993) for low-latitude mangroves, a considerable portion of Brazilian north coast mangroves produces but a fraction of this maximum. Therefore, litter fall-based primary productivity estimates will require careful evaluation of the contribution made by the different forest types and their characteristic litter fall volume.

Interestingly, all mangrove tree species within our study area show certain phenological patterns. As the temperature regime of coastal areas near the equator is comparatively even, rain fall seasonality with its marked influence on the salinity of coastal water bodies is the most promising trigger for initiation/termination of phenophases. Observing correlations of rain fall/salinity with water balance, reserve substance accumulation and phytohormon levels during the course of the year would shed light on the underlying physiological processes; however, such studies have not yet been conducted anywhere in mangroves.

The distribution of two of the species of the genus Rhizophora, $R$. racemosa and $R$. harrisonii, is disjunct with distribution centres in the Marajó Bay (Pará state) and the River Preguiças estuary. Mangroves of Marajó Bay (Pará state) are strongly influenced by freshwater through the discharge of the River Tocantins, River Pará and other rivers leading to the Bay. In contrast, the neighbouring section of the coast of Pará is characterised by higher salinity levels. Inability of these species to cope with higher salinity, or to compete with congeneric $R$. mangle and other mangrove trees under high salinity conditions is a suggestive explanation. However, salinity data are not available for the Preguiças estuary, neither are data on possible genetic isolation of the two populations which would provide hints for an explanation of the biogeographic history of these Rhizophora species in Brazil. In addition, the assumed physiological differences between $R$. racemosa and $R$. harrisonii on one hand and $R$. mangle on the other still have to be confirmed experimentally, as mentioned before.

In contrast to mangroves in other regions of Brazil (e. g., Soares, 1999), Amazonian mangroves are well preserved, possibly due to the still less severe population pressure in the coastal regions of the study area, and due to the more difficult access (Lara, 2003). Nevertheless, mangroves are endangered by population growth, deforestation for a variety of purposes, among them the increasing demand for wood (Senna et al., 2002; Szlafsztein, 2003). Policy initiatives are required for the effective preservation of mangrove forests along the Brazilian north coast. The before-mentioned approach to create RESEXM co-management reserves (Glaser and Oliveira, 2004) focuses mainly on sustainable use of resources important for the human population and on preserving traditional forms of resource extraction. To complement this, we emphasise the importance of current and future research. Continued investigation, focusing on topics such as species distribution, plant growth, adaptation to environmental factors and plant associations, is essential for the preservation of mangroves in the region.

\section{ACKNOWLEDGEMENTS}

The first author thanks CAPES (Brazil) and DAAD (Germany) for the fellowship received during the preparation of this article. Financial support was provided by the German and Brazilian Federal Ministries of Research and Technology (BMBf and $\mathrm{CNPq}$ ). This study was carried out as part of the Brazilian-German cooperative Project MADAM and was financed by the Brazilian National Research Council (CNPq) and the German Ministry for Education and Research (BMBF) under the code 03F0154A. This is MADAM contribution No. 114. 


\section{LITERATURE CITED}

Abreu, M.M. 2004. Caracterização estrutural e composição floristica em um bosque de terra firme e um manguezal da Peninsula de Ajuruteua, Bragança (Pará - Brasil). Undergraduate thesis. Federal University of Pará, Campus of Bragança. Bragança, Pará, Brazil. 33 pp.

Abreu, M. M. O.; Mehlig, U.; Nascimento, R.E.S.A.; Menezes, M.P.M. 2006. Caracterização estrutural e composição florística em um bosque de terra firme e um manguezal da península de Ajuruteua, Bragança (Pará-Brasil). Boletim do Museu Paraense Emílio Goeldi sér. Ciências Naturais 2(3):27-34.

Adams, M.; Berger, U. 2002. Regeneração e sucessão em áreas de manguezal após cultivo de arroz - Bragança, Pará. Proceedings of the VI Workshop ECOLAB. Proceedings of the VI Workshop ECOLAB, CD ROM. Belém, Pará, Brazil.

Almeida, S.S. 1996a. Estrutura florística em áreas de manguezais paraenses: evidências da influência do estuário amazônico. Boletim do Museu Paraense Emilio Goeldi. sér. Ciências da Terra. 8:93-100.

Almeida, S.S. 1996b. Identificação e avaliação de impactos ambientais e uso da flora em manguezais paraenses. Boletim do Museu Paraense Emilio Goeldi, sér. Ciências da Terra. 8:31-46.

Almeida, S.S., Overal, W.L.; Mascarenhas, B.M.; Guimarães, D.G. 2002. Flora e vegetação da microregião do salgado paraense: o caso da folha Salinópolis, estado do Pará. Proceedings of the VI Workshop ECOLAB, CD ROM. Belém, Pará, Brazil.

Alongi, D.M.; Boto, K.G.; Tirendi, F. 1989. Effect of exported mangrove litter on bacterial productivity and dissolved organic carbon fluxes in adjacent tropical near shore sediments. Marine Ecology Progress Series 56:133-144.

Amaral, D.D., Santos, J.U.; Bastos, M.N.; Costa, D.C. 2001. A vegetação da Ilha Canela, município de Bragança - Pará, Brazil. Boletim do Museu Paraense Emílio Goeldi, sér. Botânica 17(2):389-402.

Bastos, M.N. 1995. A importância das formações vegetais da restinga e do manguezal para as comunidades pesqueiras. Boletim do Museu Paraense Emilio Goeldi, sér. Antropologia 11(1):41-56.

Bastos, M.N.; Lobato, L.C. 1996. Estudos fitosociológicos em áreas de bosque de mangue na Praia do Crispim e Ilha de Algodoal. Boletim do Museu Paraense Emílio Goeldi, sér. Ciências da Terra 8:157-167.

Bastos, M.N.C.; Amaral,D.D.; Costa,D.C.T.; Santos, J.U.M.; Rosa Junior, W.O. 2002. Fitofisionomia da APA da costa do Urumajó, município de Augusto Corrêa - Pará. Proceedings of the VI Workshop ECOLAB, CD ROM. Belém, Pará, Brazil.

Batista, B. 2003. Produção de serapilheira em um manguezal sob influência de um gradiente de inundação e salinidade. Undergraduate thesis. University of Pará, Campus of Bragança. Bragança, Pará, Brazil. 30pp.

Behling, H.; Costa, M.L. 1997. Studies on Holocene tropical vegetation, mangrove and coast environments in the coast of Maranhão, NE, Brazil. Quaternary of South America and Antarctic Peninsula 10: 93-118.
Behling, H.; Cohen, M.C.L.; Lara, R.J. 2001. Studies on Holocene mangrove ecosystem development and dynamics of the Bragança Peninsula in northeastern Pará, Brazil. Palaeogeography, Palaeoclimatology, Palaeoecology 167:225-242.

Berger, U.; Glaser, M.; Koch, B.; Krause, G. ; Lara, R.J; Saint-Paul, U.; Schories, D.; Wolff, M. 1999. An integrated approach to mangrove dynamics and management. Journal of Coastal Research $5: 125-134$

Berger, U.; Adams, M.; Grimm, V.; Hildenbrandt, H. 2006. Modelling secondary succession of neotropical mangroves: causes and consequences of growth reduction in pioneer species. Trends in Plant Science and Evolution 7(4):243-252.

Berrêdo, J. F. 2006. Geoquímica dos sedimentos de manguezais do nordeste do estado do Pará: o exemplo do estuário do rio Marapanim. PhD. Thesis, Centro de Geociências, University of Pará,185 p.

Brabo, L.B. 2004. Medidas gasosas de plantas de manguezal sob diferentes condiçōes de salinidade e inundação em estufa e campo (Bragança - PA - Brazil). Master Thesis. Master of Ecology of Coastal Ecosystems, University of Pará, Campus of Bragança. Pará, Brazil. 30pp.

Breteler, F.J. 1969. The Atlantic species of Rhizophora. Acta Botanica Neerlandica. 18(3):434-440.

Carlton, J.M. 1975. A guide to common Florida Salt Marsh and mangrove vegetation. Florida Marine Research Publications number 6. Florida Department of Natural Resources. Marine Researches Laboratory. 30pp.

Carreira, L.M.; Barata, F.C.; Gurgel, E.S.; Ferreira, I.M. 2002. O pólen da vegetação de manguezal de Algodoal - I. Combretaceae, Rhizophoracaea e Verbenaceae. Proceedings of the VI Workshop ECOLAB. CD ROM. Belém, Pará, Brazil.

Carvalho, E. A. 2000. Impactos ambientais na zona costeira: o caso da estrada Bragança-Ajuruteua, estado do Pará. Master thesis. Master of Environmental Science, University of São Paulo. 82pp.

Carvalho, M.L. 2002. Aspectos da produção primária dos bosques de mangue do Furo Grande, Bragança, Pará, Brasil. Master Thesis. Master of Ecology of Coastal Ecosistems. University of Pará, Campus of Bragança. Bragança, Pará, Brazil. 55pp.

Cohen, M.C.; Lara, R.J. 2003. Temporal changes of mangrove vegetation boundaries in Amazonia: application of GIS and remote sensing techniques. Wetlands Ecology and Management 11:223-23.

Cohen, M.C.L., Lara, R.J.; Szlafsztein, C.; Dittmar, T. 2004 Mangrove inundation and nutrient dynamics from a GIS perspective. Wetlands Ecology and Management 12:81-86.

Costa-Neto, S.V., Senna, C.; Lobato, L.C.B. 2000. Estrutura e diversidade de bosques de manguezal da Baía de Marapanim, Pará, Brasil. Mangrove 2000 Conference. Full Papers - CD Rom. Recife, Brazil.

Damasio, E. 1980a. Contribuição ao conhecimento da vegetação dos manguezais da Ilha de São Luis - MA - Parte I. Boletim do Laboratório de Hidrobiologia de São Luis, Maranhão 3(1):1756.

Damasio, E. 1980b. Contribuição ao conhecimento da vegetação dos manguezais da Ilha de São Luis - MA - Parte II. Boletim do 
Laboratório de Hidrobiologia de São Luis, Maranhão 3(1):5776.

DHN - Departamento de hidrografia e navegação. 2004. Tábua de marés para 2004 - costa do Brasil e alguns portos estrangeiros. Rio de Janeiro.

Ewel, K.C.; Twilley, R.R.; Ong, J.E. 1998. Different kinds of mangrove provide different goods and services. Global Ecology and Biogeography Letters 7(1):83-94.

Ferreira, C.P. 1989. Manguezais do estado do Pará: fauna de galerias perfuradas por Teredo em toras de Rhizophora. PhD thesis. UNICAMP. Campinas, São Paulo. 150pp.

Fisch, G.; Marengo, J. A.; Nobre, C. 1998. Uma revisão geral sobre o clima da Amazônia. Acta Amazonica 28(2):101-126.

Gama, J.R.V., Bentes, M.P.; Tourinho, M.M. 1996. Composição florística e fitossociológica de um ecossistema de mangue no nordeste paraense. Anais do I Workshop sobre as potencialidades de uso do ecossistema de várzeas da Amazônia - EMBRAPA. Boa Vista, Roraima, Brazil. p.114-120.

Glaser, M.; Grasso, M. 1998. Fisheries of a mangrove estuary: dynamics and interrrelationships between economy and ecosystem in Caeté Bay, North-Eastern Pará, Brazil. Boletim do Museu Paraense Emilio Goeldi. sér. Zoologia. 14:95-125.

Glaser, M. 2003. Interrelations between mangrove ecosystem, local economy and social sustainability in Caeté Estuary, north Brazil. Wetlands Ecology and Management 11:265-272.

Glaser, M.; Berger, U.; Macedo, R. 2003. Local vulnerability as an advantage: mangrove forest management in Pará state, north Brazil, under conditions of illegality. Regional Environmental Changes 3:162-172.

Glaser, M.; Oliveira, R. S. 2004. Prospects for the co-management of mangrove ecosystems on the North Brazilian coast: whose rights, whose duties and whose priorities? Natural Resources Forum 28:224-233.

Herz, R. 1991. Manguezais do Brasil. Instituto Oceanográfico, Universidade de São Paulo. São Paulo. 227pp.

Hu, H. 2004. Effects of potential stress factors on chlorophyll fluorescence in four mangrove species in Bragança, north Brazil. Master Thesis. International Science Tropical Ecossystems (ISATEC), ZMT. Bremen, Germany. 74pp.

Kjerfve, B.; Lacerda, L.D. 1992. Mangroves of Brazil. In: Lacerda, L.D. (org.) Conservation and sustainable utilization of mangrove forests in latin America and Africa regions. Part I. Latin America. Vol. 2. ISME.

Krause, G.; Schories, D.; Glaser, M.; Diele, K. 2001. Spatial patterns of mangrove ecosystems: the Bragantinian mangroves of northern Brazil (Bragança, Para). Ecotropica 7:93-107.

Lacerda, L.D. 1999. Os manguezais do Brasil. In: M. Vanucci. 1999. Os manguezais e nós. Edusp, CNPq. São Paulo, Brazil. 233pp.

Lara, R.J.; Cohen, M.C.L. 2002. Sensoriamento remoto. In: M.E.B. Fernandes (ed..). Os manguezais da costa norte brasileira. Fundação Rio Bacanga. Maranhão. Brazil. 139pp.
Lara, R.J. 2003. Amazonian mangroves - a multidisciplinary case study in Pará State, North Brazil: introduction. Wetlands Ecology and Management 11:217-221.

Lara, R.J.; Cohen, M.C.L. 2006. Sediment porewater salinity, inundation frequency and mangrove vegetation height in Bragança, North Brazil: an ecohydrology-based empirical model. Wetlands Ecology and Management 14:349-358.

Lima, R.R.; Tourinho, M.; Costa, J.P.C. 2000. Várzeas fluviomarinhas da Amazônia brasileira: características e possibilidades agropecuárias. FCAP - Belém, Pará, Brazil. 341pp.

Lima, T.C.M.; Paoli, A.A.S.; Girnos, E.C. 2005. Morfo-Anatomia foliar do gênero Rhizophora L. In: M.E.B. Fernandes (ed.). Os manguezais da costa norte brasileira Vol.2. Fundação Rio Bacanga. Maranhão. Brazil. 165pp.

Lisboa, P.L.B.; Lisboa, R.C.L.; Rosa, N.A.; Santos, M.R. 1993. Padróes de diversidade florística na reserva ecológica do Bacurizal, em Salvaterra, Ilha do Marajó. Boletim do Museu Paraense Emílio Goeldi, sér. Botânica 9(2):223-248.

Luz, L.M.; Prost, M.T.; Mendes, A.C.; Berrêdo, J.F. 2000. Interações entre gradientes de sucessão de manguezais e dinâmica costeira: o exemplo da Ilha Nova - São Caetano de Odivelas/ Pará/Brasil. Proceedings of the VWorkshop ECOLAB. Macapá, Amapá, Brazil. p. $159-163$.

Matni, A. 2003. Estrutura dos bosques de mangue da península de Bragança, Pará, Brasil. Undergraduate thesis. University of Pará, Campus of Bragança. Bragança, Pará, Brazil. 30pp.

Matni, A. S.; Menezes, M. P. M.; Mehlig; U. 2006. Estrutura dos bosques de mangue da península de Bragança, Pará, Brasil. Boletim do Museu Paraense Emílio Goeldi. Sér. Ciências Naturais 2 (3): 45-54.

Macnae, W. 1968. A general account of the fauna and the flora of mangrove swamps and forests in the west-pacific region. Advance Marine Biology 6:73-270.

Medina, E.; Giarrizzo, T.; Menezes, M.P.; Carvalho, M.L.; Carvalho, E.A.; Peres, A.; Silva, A.B.; Villhena, R.; Reise, A.; Braga, C. 2001. Mangal communities of the Salgado Paraense: Ecological heterogeneity along the Bragança peninsula assessed through soil and leaf analysis. Amazoniana XVI (3/4):397-416.

Mehlig, U. 2001. Aspects of tree primary production in an equatorial mangrove forest in Brazil. ZMT Contribution 14. Center for Marine Tropical Ecology (ZMT) Bremen, Germany. 155pp.

Mehlig, U.; Menezes, M.P.M. 2005. Mass defoliation of the mangrove tree Avicennia germinans by the moth Hyblaea puera (lepidoptera Hyblaeidae) in Equatorial Brazil. Ecotropica 11: 87-88.

Mehlig, U. 2006. Phenology of the red mangrove, Rhizophora mangle L., in the Caeté estuary, Pará, Equatorial Brazil. Aquatic Botany 84:158-164.

Mello, C.P.; Carvalho, E.A.; Silva, N.S. M.; Menezes, M.P.M.; Almeida, L.F. 1995. As angiospermas de alguns manguezais paraenses. Proceedings of the III Workshop ECOLAB. Belém, Pará, Brazil. p:108-110.

Menezes, M.P.M. 1994. Caracterização estrutural dos bosques de mangue do rio Curuperé, no município de Curuçá (Pa). 
Undergraduate thesis. University of Pará. Belém, Pará, Brazil. 38pp.

Menezes, M.P.M. 1997. Mécanisme de pollinisation du paletuvier Rhizophora mangle dans des mangroves en Amazonie, Brésil. Master thesis. Univesité du Quebec à Montréal. Montréal, Québec, Canada. 75pp.

Menezes, M.P.M.; Compton, A.T.K. 2003. An analysis of the vegetation related to the inundation level of a degraded mangrove forest: Bragança, Peninsula, NE Brazil. Proceedings of the Mangrove 2003 Conference. Salvador, Bahia, Brazil.

Menezes, M.P.M.; Berger, U.; Worbes, M. 2003a. Annual growth rings and long-term growth patterns of mangrove trees from the Bragança peninsula, North Brazil. Wetlands Ecology and Management 11:233-243.

Menezes, M.P.M.; Sales, J.B.; Nascimento, J.R.; Rodrigues, L.F. 2003b. Vegetação dos bosques de mangue do rio Gurupi, município de Vizeu, Pará, Brasil. Proceedings of the Mangrove 2003 Conference. Salvador, Bahia, Brazil.

Menezes, M.P.M.; Mehlig, U. 2005. Desfolhação maciça de árvores de Avicennia germinans (L.) Stearn 1958 (Avicenniaceae) por Hyblaea puera (Lepidoptera: Hyblaeidae), nos manguezais da península de Bragança, Pará, Brasil. Boletim do Museu Paraense Emilio Goeldi, sér. Ciências Naturais 1(1):221-226.

Nascimento, R.E.S.A.; Mehlig, U.; Abreu, M.M.O.; Menezes, M.P.M. 2006. Produção de serapilheira em um fragmento de bosque de terra firme e um manguezal vizinhos na península de Ajuruteua. Boletim do Museu Paraense Emílio Goeldi. Sér. Ciências Naturais 2(3):45-54.

Nordhaus, I. 2004. Feeding ecology of the semi-terrestrial crab Ucides cordatus cordatus (Decapoda: Brachyura) in a mangrove forest in northern Brazil. ZMT Contribution 18. Center for Marine Tropical Ecology (ZMT). 198pp.

Nordhaus, I.; Wolff, M.; Diele, K. 2006. Litter processing and population food intake of the mangrove crab Ucides cordatus in a high intertidal forest in northern Brazil. Estuarine Coastal and Shelf Science 67:239-250.

Ohana, F.M.; Praxedes, C.; Mello, C.F.; Anjos, C.R. 1996. Levantamento preliminar de organismos fitófagos em plantas de mangue do rio Curuperé-Curuçá (PA). Anais do $3^{\circ}$ Congresso de Ecologia do Brasil. Belém, Pará, Brazil.

Pontes, A.V.Q.; Mochel, F.R. 2000. Análise de herbivoria em folhas de manguezais submetidos a impactos naturais e antrópicos na praia do Araçagi, Maranhão, Brasil. Proceedings of the VWorkshop ECOLAB. Macapá, Amapá, Brazil. p. 273-278.

Prance, G.T.; Silva, M.F.; Albuquerque, B.; Araújo, I.J.F.; Carreira, L.M.; Braga, M.M.; Macedo, M.; Conceição, P.N.; Lisboa, P.L.; Braga, P.I.; Lisboa, R.L.; Vilhena, R.Q. 1975. Revisão taxonômica das espécies amazônicas de Rhizophoraceae. Acta Amazonica 5(1):5-22.

Praxedes, C.; Mello, C.F. 1998. Análise preliminar dos aspectos biológicos de galhas em plantas de mangue no manguezal de Ajuruteua-Bragança (PA). Proceedings of the $4^{\circ}$ Congresso de Ecologia do Brasil. Belém, Pará, Brazil. p. 459.
Praxedes, C.; Mello, C.F.; Colombi, J. 1998. Caracterização de galhas entomógenas na vegetação típica de mangue no manguezal de Ajuruteua-Bragança (PA). Proceedings of the $4^{\circ}$ Congresso de Ecologia do Brasil. Belém, Pará, Brazil. p. 460.

Prost, M.T; Loubry, D. 2000. Estrutura de espécies de manguezais e processos geomorfológicos: interesse da abordagem integrada. Proceedings of the VWorkshop ECOLAB. Macapá, Amapá, Brazil. p. $147-151$.

Prost, M.T.; Mendes, A.C.; Faure, J.F.; Berredo, J.F.; Sales, M.E.; Furtado,L.G.; Santana, M.G.; Silva, C.A.; Nascimento, I.; Gorayeb, I.; Secco, M.F.; Luz, L. 2001. Manguezais e estuários da costa paraense: exemplo de estudo multidisciplinar integrado (Marapanim e São Caetano de Odivelas). In: Prost, M.T and Mendes, A. (orgs.) Ecossistemas costeiros: impactos e gestão ambiental. FUNTEC and Museu Paraense Emílio Goeldi. 215 pp.

Rebelo-Mochel, F. 1997. Mangrove ecosystems in São Luis Island, Maranhão, Brazil. In: Kjerve, B; Lacerda, L.D. and H. Diop (Eds.). Mangrove ecosystems in Latin America and Caribbean. UNESCO, Paris. 347pp.

Rebelo-Mochel, F. 2000. Structural variability of mangrove forests influenced by seawater in Turiaçú bay, Amazonian coast of Maranhão, Brazil. Proceedings of the Mangrove 2003 Conference. Recife, Brazil.

Rebelo-Mochel, F. M.; Cutrim, M.M.; Correia, M.S.; Ibanez, A.C.; Azevedo, V.M.; Oliveira, C.; Pessoa, D.C.; Maia, P.C.; Silveira, M.; Ibañez-Roja, G.; Pacheco, C.; Costa, L.; Puisseck, A. 2001. Degradação dos manguezais da ilha de São Luis (MA): precessos naturais e impactos antrópicos. In: Prost, M.T and Mendes, A. (orgs.) Ecossistemas costeiros: impactos e gestão ambiental. FUNTEC, Museu Paraense Emílio Goeldi. 215 pp.

Reise, A. 1999. Untersuchungen zum Streufall und Streuumsatz als Basis zur Charakterisierung des Stofflusses in verschieden strukturierten Mangrovenwäldern Braganças/Nordostbrasiliens. Diploma thesis. University of Lüneburg. Lüneburg, Germany. 81pp.

Reise, A. 2003. Estimates of biomass and productivity in fringe mangroves of North-Brazil. ZMT Contribution 16. Center for Marine Tropical Ecology (ZMT) Bremen, Germany. 196pp.

Saenger, P.; Snedaker, S.C. 1993. Pantropical trends in mangrove above-ground biomass and annual litterfall. Oecologia 96: 293-299.

Sales, M.E. 2000. Decomposição de folhas de espécies de manguezal na região de São Caetano de Odivelas, Costa nordeste do Pará. Mangrove 2000 conference. Full Papers - CD ROM. Recife, Brazil.

Sales, J.B.L; Nascimento, J.R.; Rodrigues, L.F.; Matni, A.S.; Menezes, M.P.M. 2004. Composição estrutural dos bosques de mangue de São João de Pirabas, nordeste do estado do Pará, Brasil. Proceedings of the $55^{\circ}$ Congresso Brasileiro de Botânica. CD ROM. Viçosa, Minas Gerais, Brazil.

Sales, J.B.L. 2005. Caracterização estrutural dos bosques de mangue do rio Cajutuba, Marapanim, Pará, Brasil. Undergraduate thesis. University of Pará, Campus of Bragança. Bragança, Pará, Brazil. 20pp. 
Santana, G. 2001. Formas organizativas e estratégias de vida no litoral paraense. In: Prost, M.T. and A. Mendes (eds.). Ecossistemas costeiros: impactos e gestão ambiental. Museu Paraense Emílio Goeldi. FUNTEC and Museu Paraense Emílio Goeldi. Belém, Pará, Brazil. 215pp.

Santos, C.L. 2005. Fenologia de Avicennia L. em dois sitios na península de Ajuruteua, Bragança, Pará. Undergraduate thesis. University of Pará, Campus of Bragança. Bragança, Pará, Brazil. 20pp.

Santos, M. 1986. Considerações sobre a ocorrência de Rhizophora harrisonii Leechman e Rhizophora racemosa G.F.W. Meyer, no litoral do estado do Maranhão, Brasil. Boletim do Laboratório de Hidrobiologia São Luis, Maranhão 7:71-91.

Santos, M.V.; Zieman, J.C.; Cohen, R.H. 1997. Interpreting the upper mid-littoral zonation patterns of mangroves in Maranh ão (Brazil) in response to microtopography and hydrology. In: B. Kjerfve, L.D. Lacerda and E. H. Diop (eds.). Mangrove ecosystem studies in Latin America and Africa. UNESCO. Paris. 149pp.

Santos, J.U.; Amaral, D.D.; Gorayeb, I.; Bastos, M.N.; Secco, R.; Costa Neto, S.V.; Costa, D.T. 2003. Vegetação da área de proteção ambiental Jabotitiua-Jatium, município de Viseu, Pará, Brasil. Acta Amazônica 33(3):431-444.

Sasekumar, A.; Chong, V.V.; Leh, M.; D’Cruz, R. 1992. Mangroves as habitat for fish and prawns. Hydrobiologia 247:195-207.

Schaeffer-Novelli, Y.; Cintron, G.; Adaime, R.R.; Camargo, T.M. 1990. Variability of mangrove ecosystems along the Brazilian coast. Estuaries 13:204-218.

Schories, D.; Reise, A. 2000. Forest structure and litter production in fringe mangroves of north Brazil. Mangrove conference - 2000 . Full Paper - CD Rom. Recife, Brazil.

Schories, D.; Barletta-Bergan, A.; Barletta, M.; Krumme, U.; Mehlig, U.; Rademaker, V. 2003. The keystone role of leaf-removing crabs in mangrove forests of north Brazil. Wetlands Ecology and Management 11:243-255.

Seixas, J.A.S. 2003. Estudo comparativo da estrutura da vegetação dos bosques de mangue do Furo Grande, Bragança, PA. Undergraduate thesis. Federal University of Pará, Campus of Bragança. Bragança, Pará, Brazil. 26pp.

Seixas, J.G.S.; Fernandes, M.E.B.; Silva, E. 2006. Análise estrutural da vegetação arbórea dos mangues no Furo Grande, Bragança, Pará. Boletim do Museu Paraense Emílio Goeldi, sér. Ciências Naturais 2(3): 35-43.

Senna, C.; Mello, C.F.; Furtado, L.G. 2002. Impactos naturais e antrópicos em manguezais do estado do Pará. In: Furtado, L. and Quaresma, H.D.A.B (eds). Gente e ambiente no mundo da pesca artesanal. Museu Paraense Emílio Goeldi. Belém, Pará, Brazil. 258pp.

Silva, R.M. 2005. Fenologia de Laguncularia racemosa (L.) Gaertn. f. em três bosques de manguezal na peninsula de Ajuruteua, Pará, Brasil. Undergraduate thesis. University of Pará, Campus of Bragança. Bragança, Pará, Brazil. 21pp.

Silveira, P.C.; Mochel, F.R. 2000. Indicadores sócio-econômicoambientais e recursos faunísticos comercializados em um manguezal sob impactos de atividades humanas em Parnauaçu, Maranhão, Brasil. Proceedings of the VWorkshop ECOLAB. Amapá, Macapá, Brazil. p. 289-295.

Soares, M.L.G. 1999. Estrutura vegetal e grau de perturbação dos manguezais da Lagoa da Tijuca, Rio de Janeiro, TJ, Brasil. Revista Brasileira de Botânica 14:21-25.

Sousa, L.A. 2001. Estudo do ataque da mariposa Hyblaea puera Cramer (Lepidoptera: Hyblaeiidae) em árvores de siriúba (Avicennia germinans L. - Verbenaceae) em manguezais do estado do Pará, Brasil. Proceedings of the Seminário de Iniciação Cientifica do Museu Paraense Emílio Goeldi. Belém, Pará, Brazil. p. 76.

Souza-Filho, P.W. 2001. Impactos naturais e antrópicos na planície costeira de Bragança (NE do Pará). In: Prost, M.T. and A. Mendes (eds.). Ecossistemas costeiros: Impactos e gestão ambiental. Museu Paraense Emílio Goeldi. 215pp.

Souza-Filho, P.W.; Paradella, W.R. 2002. Recognition of the main geobotanical features along the Bragança mangrove coast (Brazilian Amazon region) from Landasat TM and RADARSAT-1 data. Wetlands Ecology and Management 10:123-132.

Souza-Filho, P.W. 2005. Costa de manguezais de macromaré da Amazônia: cenários morfológicos, mapeamento e quantificação de áreas usando dados de sensores remotos. Revista Brasileira de Geofisica 23(4):427-435.

Spalding, M.; Blasco, F.; Field, C.D. (eds). 1997. World mangrove atlas. The international Society for Mangrove Ecosystems, Okinawa, Japan. 178pp.

Szlafsztein, C. 2003. Vulnerability and response measures to natural hazards and sea level rise impacts: long-term coastal zone management, NE of the state of Pará, Brazil. ZMT Contributions 17. Center for Marine Tropical Ecology (ZMT). Bremen, Germany. 192pp.

Thüllen, N. 1997. Analyse der Struktur eines Mangrovenwaldgebietes bei Bragan ça, Nordbrasilien und Untersuchungen ihr zugrunde liegender abiotischer und biotischer Faktoren. Diplomarbeit, Center for Marine Tropical Ecology (ZMT), Bremen, Germany. $129 \mathrm{pp}$.

Thüllen, N.; Berger, U. 2000. A comparative examination of environmental factors at patchy mangrove seedling stands on the peninsula of Bragança, northern Brazil. Ecotropica 6:1-12.

Tomlinson, P.B. 1986. The Botany of mangroves. Cambridge University Press. Cambridge. 418pp.

Tourinho, D.M. 1998. Composição florística e estrutura da vegetação em diferentes estágios sucessionais de uma área de mangue em Acarajó, Bragança, Pará, Brasil. Master thesis. Faculty of Agrarian Science - FCAP. Belém, Pará. Brazil. 64pp.

Recebido em 05/04/2006

Aceito em 19/02/2008 
Annex 1 - Occurrence of Rhizophora species along the coast of Pará and Maranhão states. MG indicates data from the herbarium of MPEG .

\begin{tabular}{|c|c|c|c|c|c|}
\hline Local & $\mathrm{Rm}$ & $\mathbf{R r}$ & $\mathbf{R h}$ & References & Position \\
\hline \multicolumn{6}{|l|}{ Pará State } \\
\hline Afuá & $\bullet$ & & & Maciel and col. 1842 (MG 144453) & $0^{\circ} 09^{\prime} 56^{\prime \prime} S ; 50^{\circ} 24^{\prime} 8^{\prime \prime} W$ \\
\hline Ananindeua & & $\bullet$ & & Ferreira (1989) & 1²2'12's;48²2'42'”W \\
\hline Augusto Corrêa: Urumajó & $\bullet$ & & & $\begin{array}{l}\text { Carreira and col. } 1462 \text { (MG 165749), Bastos et al. } \\
\text { (2000); Bastos et al. (2002) }\end{array}$ & $1^{\circ} 01^{\prime} 12^{\prime \prime} \mathrm{S} ; 46^{\circ} 39^{\prime} 33^{\prime \prime} \mathrm{W}$ \\
\hline $\begin{array}{l}\text { Barcarena: Rio Caripi, Vila São } \\
\text { Vicente }\end{array}$ & & • & & Lins and col. 338 (MG 115416) & 1³0’60"S;48`37’53”W \\
\hline $\begin{array}{l}\text { Belém: Ilha das Onças, Ilha da } \\
\text { Tatuoca }\end{array}$ & • & $\bullet$ & & $\begin{array}{l}\text { Prance et al (1975); Almeida and Lobato } 376 \text { (MG } \\
\text { 135338) }\end{array}$ & 1²6’22"S;48³3’47' W \\
\hline Benevides: Benfica & & $\bullet$ & & Rosa and Renner (MG 0147650); Ferreira (1989) & 1²1'49'”S;48¹5’7'W \\
\hline $\begin{array}{l}\text { Bragança: Península de Ajuruteua, } \\
\text { Ilha de Canelas }\end{array}$ & • & & & $\begin{array}{l}\text { Almeida (1996b); Thüllen and Berger (2000); Krause et } \\
\text { al. (2001); Amaral et al. (2001); Menezes et al. (2003); } \\
\text { Matni, (2003); Seixas (2003); Abreu (2004) }\end{array}$ & $1^{\circ} 03^{\prime} 06^{\prime \prime} \mathrm{S} ; 46^{\circ} 45^{\prime} 44^{\prime \prime} \mathrm{W}$ \\
\hline Colares & & $\bullet$ & & Almeida (1996a) & 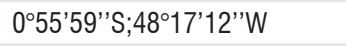 \\
\hline Curuçá & $\bullet$ & & & $\begin{array}{l}\text { Mello et al. (1995); Carvalho et al. (1995); Almeida } \\
\text { (1996a) }\end{array}$ & 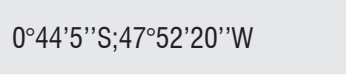 \\
\hline $\begin{array}{l}\text { Iha de Algodoal; Praia do Crispim; } \\
\text { Ilha de Maiandeua: Marudá }\end{array}$ & $\bullet$ & & & Bastos and Lobato (1996), Carreira et al. (2002) & 0³7'5"'S;47³4'14'”W \\
\hline $\begin{array}{l}\text { Illha de Mosqueiro: Praia do Maraú, } \\
\text { Praia do Paraíso }\end{array}$ & & $\bullet$ & & Prance et al. (1975) & 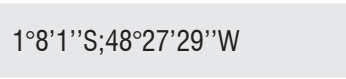 \\
\hline $\begin{array}{l}\text { Marajó: Breves, Salvaterra, Soure, } \\
\text { São Sebastião da Boa Vista }\end{array}$ & $\bullet$ & • & & $\begin{array}{l}\text { Lisboa et al. (1993); Rosa and col. } 5469 \text { (MG } \\
\text { 143964); Rosa and col. } 5547 \text { (MG 144042) }\end{array}$ & $0^{\circ} 41^{\prime} 53^{\prime \prime S}$; $48^{\circ} 31^{\prime} 15^{\prime \prime} \mathrm{W}$ \\
\hline Marituba & $\bullet$ & - & & Almeida (1996a) & 1²1'20"S;48²0'14”'W \\
\hline $\begin{array}{l}\text { Marapanim: Rio Marapanim, Rio } \\
\text { Mojuim, Rio Cajutuba }\end{array}$ & $\bullet$ & & & $\begin{array}{l}\text { Prost and Loubry (2000); Costa-Neto et al. (2000); } \\
\text { Prost et al. (2001); Sales (2005); Berredo (2005) }\end{array}$ & 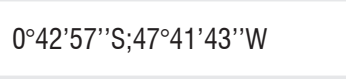 \\
\hline Primavera, & $\bullet$ & & & Almeida (1996a) & 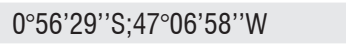 \\
\hline Quatipuru & $\bullet$ & & & Huber 1899 (MG 1766); Almeida et al. (2002) & \\
\hline Salinas: Rio Sampaio & $\bullet$ & $\bullet$ & $\bullet$ & Prance et al. (1975); Ferreira (1989) & 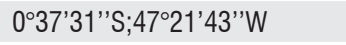 \\
\hline Santa Bárbara & & - & & Santos et al. 2 (MG 172748) & 1¹3'16"S;48¹7'36"'W \\
\hline São Caetano de Odivelas & • & & & $\begin{array}{l}\text { Prance et al. (1975); Ferreira (1989); Sales (2000) } \\
\text { Prost and Loubry (2000); Luz et al. (2000); }\end{array}$ & 044'49'’S;48`1'17'’W \\
\hline São João de Pirabas & $\bullet$ & & & Menezes et al. (2003) & $0^{\circ} 46^{\prime} 05^{\prime \prime S} ; 47^{\circ} 10^{\prime} 44^{\prime \prime} \mathrm{W}$ \\
\hline Vigia & $\bullet$ & - & & Ferreira (1989); pers. obs. & 051'40"'s;4808'35'”W \\
\hline Viseu: Jabotitiua-Jatium & $\bullet$ & & & $\begin{array}{l}\text { Santos et al. (2003) } \\
\text { Menezes et al. (2003b) }\end{array}$ & 1¹2'18.2”S;4608'18.8”W \\
\hline \multicolumn{6}{|l|}{ Maranhão State } \\
\hline Baía de São Marcos & $\bullet$ & & & Silveira and Mochel (2000) & 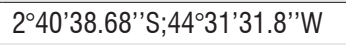 \\
\hline Golfão Maranhense & $\bullet$ & $\bullet$ & $\bullet$ & Santos (1986) & $2^{\circ} 45^{\prime} 43,43^{\prime \prime} \mathrm{S} ; 44^{\circ} 21^{\prime} 69^{\prime \prime} \mathrm{W}$ \\
\hline Rio Mearim & - & & & Behling and Costa (1997) & \\
\hline Rio Preguiças & $\bullet$ & $\bullet$ & $\bullet$ & Santos (1986) & 2³7'06.23”'S;4241'41.28'”W \\
\hline São Luis & $\bullet$ & $\bullet$ & & $\begin{array}{l}\text { Prance et al. (1975); Damasio (1980a); Rebelo-Mochel } \\
\text { (1997); Rebelo-Mochel et al. (2001); }\end{array}$ & 2³1'03”'s;44¹7’59'”W \\
\hline Turiaçu & $\bullet$ & & & Rebelo-Mochel (2000) & $1^{\circ} 40^{\prime} 15^{\prime \prime} \mathrm{S} ; 45^{\circ} 22^{\prime} 01^{\prime \prime} \mathrm{W}$ \\
\hline
\end{tabular}


Annex 2 - Occurrence of Avicennia species along the coast of Pará and Maranhão states. MG indicates data from the herbarium of MPEG .

\begin{tabular}{|c|c|c|c|}
\hline Local & $\mathrm{Ag} \mathrm{As}$ & Reference & Position \\
\hline \multicolumn{4}{|l|}{ Pará State } \\
\hline $\begin{array}{l}\text { Ananindeua: Maguarizinho, Rio } \\
\text { Seco, Curuçambá }\end{array}$ & $\bullet$ & Ferreira (1989) & $1^{\circ} 22^{\prime} 12^{\prime \prime} \mathrm{S} ; 48^{\circ} 22^{\prime} 42^{\prime \prime} \mathrm{W}$ \\
\hline Augusto Correa: Urumajó & $\bullet$ & $\begin{array}{l}\text { Carreira and col. } 1449 \text { (MG 165737); Bastos et } \\
\text { al. (2002) }\end{array}$ & $1^{\circ} 01^{\prime} 12^{\prime \prime} \mathrm{S} ; 46^{\circ} 39^{\prime} 33^{\prime \prime} \mathrm{W}$ \\
\hline Barcarena & $\bullet$ & Lins and col. 103 (MG 113223) & $1^{\circ} 30^{\prime} 60^{\prime \prime} \mathrm{S} ; 48^{\circ} 37^{\prime} 53^{\prime \prime} \mathrm{W}$ \\
\hline Belém: Ilha das Onças & $\bullet$ & Huber 1903 (MG 3832) & $1^{\circ} 26^{\prime} 22^{\prime \prime} \mathrm{S} ; 48^{\circ} 33^{\prime} 47^{\prime \prime} \mathrm{W}$ \\
\hline Benevides: Igarapé Estaleiro & $\bullet$ & Ferreira (1989) & 1²1'49'S; $48^{\circ} 15^{\prime} 7^{\prime \prime} W$ \\
\hline $\begin{array}{l}\text { Bragança: Península de Ajuruteua, } \\
\text { llha de Canelas, Praia de Ajuruteua }\end{array}$ & $\bullet \bullet$ & $\begin{array}{l}\text { Almeida (1996a); Thüllen (1997); Amaral et al. } \\
\text { (2001); Matni (2003); Seixas (2003); Brabo } \\
\text { (2004); Abreu (2004); Santos (2005) }\end{array}$ & $1^{\circ} 03^{\prime} 06^{\prime \prime} \mathrm{S} ; 46^{\circ} 45^{\prime} 44^{\prime \prime} \mathrm{W}$ \\
\hline Curuçá & - • & $\begin{array}{l}\text { Menezes (1994); Carvalho et al. (1995); Almeida } \\
\text { (1996a); Mello et al. (1995) }\end{array}$ & $0^{\circ} 44^{\prime} 5^{\prime \prime} \mathrm{S} ; 47^{\circ} 52^{\prime} 20^{\prime \prime} \mathrm{W}$ \\
\hline Colares & $\bullet$ & Almeida (1996a) & 055'59”'s;48॰17'12'”W \\
\hline Igarapé do Japim & - & Duke, 1895 (MG) & no information \\
\hline $\begin{array}{l}\text { llha de Algodoal: Maiandeua, } \\
\text { Maracanã, }\end{array}$ & - & Bastos and Lobato (1996); Carreira et al. (2002) & 0³7'5"'s;47³4'14'”W \\
\hline Ilha de Marajó: Pacorral, Salvaterra & $\bullet$ & Gress 1899, 1915 (MG); Lisboa et al. (1993); & 041'53'”; 48³1'15'”W \\
\hline $\begin{array}{l}\text { Marapanim:Rio Marapanim, Rio } \\
\text { Cajutuba }\end{array}$ & $\bullet$ & $\begin{array}{l}\text { Prost and Loubry (2000); Costa-Neto et al. } \\
\text { (2000); Sales (2005);Berredo (2005) }\end{array}$ & 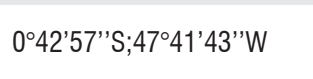 \\
\hline Marituba, Mosqueiro & $\bullet$ & Almeida (1996a); Ferreira (1989) & 1'21'20'”; 48²0'14'”W \\
\hline Marudá, Crispim & $\bullet$ & Bastos and Lobato (1996) & 0³7'5”'S;47³4'14'”W \\
\hline Primavera, Quatipuru, Boa Vista & $\bullet$ & $\begin{array}{l}\text { Almeida (1996a), Rodrigues } 5072 \text { (MG 35584); } \\
\text { Almeida et al. (2002) }\end{array}$ & 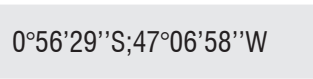 \\
\hline Salinas: Rio Sampaio & $\bullet$ & Ferreira (1989) & 0॰37’31'"S;47²1'43”'W \\
\hline $\begin{array}{l}\text { São Caetano de Odivelas:Rio } \\
\text { Araciteua, Ilha Nova, Rio Mojuim }\end{array}$ & $\bullet \bullet$ & $\begin{array}{l}\text { Ferreira (1989); Luz et al. (2000); Prost and } \\
\text { Loubry (2000); Prost et al. (2001) }\end{array}$ & $0^{\circ} 44^{\prime} 49^{\prime \prime} \mathrm{S} ; 48^{\circ} 1^{\prime \prime 1} 7^{\prime \prime} \mathrm{W}$ \\
\hline São João de Pirabas & - • & Sales et al., 2004 & $0^{\circ} 46^{\prime} 05^{\prime \prime} \mathrm{S} ; 47^{\circ} 10^{\prime} 44^{\prime \prime} \mathrm{W}$ \\
\hline Vigia & $\bullet$ & Ferreira (1989); Mello et al., 1995 & 0॰51'40”'S;4808'35'”W \\
\hline Viseu: Jabotitiua Jatium & $\bullet$ & Santos et al. (2003); Menezes et al. (2003b) & $1^{\circ} 12^{\prime} 18.2^{\prime \prime} \mathrm{S}, 46^{\circ} 08^{\prime} 18.8^{\prime \prime} \mathrm{W}$ \\
\hline \multicolumn{4}{|l|}{ Maranhão State } \\
\hline Alcântara & - • & Rosa and Silva 2509 (MG 132535); pers. obs & $2^{\circ} 24^{\prime} 27^{\prime \prime} \mathrm{S} ; 44^{\circ} 25^{\prime} 22^{\prime \prime} \mathrm{W}$ \\
\hline Baia de São Marcos & $\bullet$ & Silveira and Mochel (2000) & 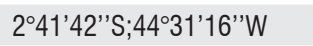 \\
\hline Parnauaçu & $\bullet \bullet$ & Rebelo-Mochel et al., (2001) & 2³7'27'"S;44²1'41'”W \\
\hline Estreito de Coqueiros, São Luis & $\bullet$ & Santana (MG 69921) & 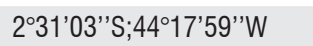 \\
\hline São Luis & • & $\begin{array}{l}\text { Fern and Rob } 96 \text { (MG 129408); Damasio (1980a); } \\
\text { Rebelo-Mochel (1997); Rebelo-Mochel et al. } \\
\text { (2001) }\end{array}$ & $2^{\circ} 31^{\prime} 03^{\prime \prime} \mathrm{s} ; 44^{\circ} 17^{\prime} 59^{\prime \prime \prime} \mathrm{W}$ \\
\hline
\end{tabular}


Annex 3 - Occurrence of Laguncularia racemosa along the coast of Pará and Maranhão states. MG indicates data from the herbarium of MPEG .

\begin{tabular}{|c|c|c|}
\hline Local & Reference & Position \\
\hline \multicolumn{3}{|l|}{ Pará State } \\
\hline Ananindeua - Igarapé Curuçamba & Fereira (1989); Mello et al. (1995); & 1²2'12”S;48²2'42”W \\
\hline Braganca & $\begin{array}{l}\text { Almeida (1996a); Tourinho (1998); Amaral et al. (2001); } \\
\text { Menezes et al. (2003); Menezes and Compton (2003) }\end{array}$ & $1^{\circ} 03^{\prime} 06^{\prime \prime} \mathrm{S} ; 46^{\circ} 45^{\prime} 44^{\prime \prime} \mathrm{W}$ \\
\hline Colares & Almeida (1996a) & 055’59”S;48¹7’12”'W \\
\hline Curuçá & Menezes (1994); Mello et al. (1995) & 044'5"S;4752'20'W \\
\hline Ilha de Algodoal & Bastos and Lobato (1996); Carreira et al. (2002) & 0³7'5'”S;47³4'14'”W \\
\hline Ilha de Mosqueiro & Almeida (1996a) & $1^{\circ} 8^{\prime} 1^{\prime \prime} S ; 48^{\circ} 27^{\prime} 29^{\prime \prime} W$ \\
\hline Marapanim & Luz et al. (2000); Costa-Neto et al. (2000); Sales (2005) & $0^{\circ} 42^{\prime} 57^{\prime \prime S} ; 47^{\circ} 41^{\prime} 43^{\prime \prime} \mathrm{W}$ \\
\hline Marituba & Almeida (1996a) & 1²1'20"S;48²0'14”'W \\
\hline Primavera & Almeida (1996a) & 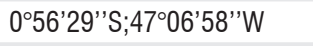 \\
\hline Salinas: Rio Sampaio & Fereira (1989); Mello et al. (1995) & 0³7’31'S;47²1'43”'W \\
\hline São Caetano de Odivelas: Rio Araciteua & Fereira (1989); Mello et al. (1995); Prost et al. (2001) & 044'49"S;48¹'17'”W \\
\hline Vigia & Pers. obs. & 0॰51'40"'S;4808'35”W \\
\hline Viseu: Jabotitiua-Jatium & Santos et al. (2003); Menezes et al. (2003b) & 1'12'18.2”S, 4608'18.8”W \\
\hline \multicolumn{3}{|l|}{ Maranhão State } \\
\hline Parnauaçu & Rebelo-Mochel (2000) & 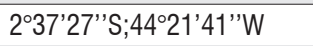 \\
\hline São Luis & $\begin{array}{l}\text { Damasio (1980a); Rebelo-Mochel (1997); Rebelo-Mochel } \\
\text { (2000); Rebelo-Mochel et al. (2001) }\end{array}$ & 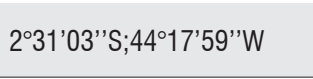 \\
\hline
\end{tabular}


